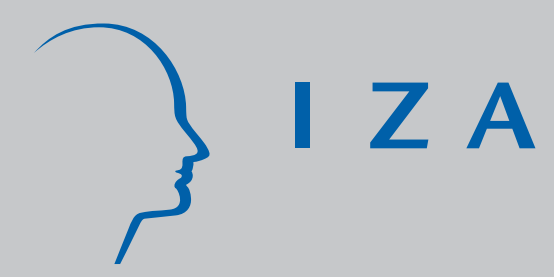

IZA DP No. 2720

Reducing Income Transfers to Refugee Immigrants: Does Starthelp Help You Start?

Michael Rosholm

Rune M. Vejlin

April 2007 


\title{
Reducing Income Transfers to Refugee Immigrants: Does Starthelp Help You Start?
}

\author{
Michael Rosholm \\ University of Aarhus \\ and IZA \\ Rune M. Vejlin \\ University of Aarhus
}

\section{Discussion Paper No. 2720 \\ April 2007}

IZA

P.O. Box 7240

53072 Bonn

Germany

Phone: +49-228-3894-0
Fax: +49-228-3894-180
E-mail: iza@iza.org

Any opinions expressed here are those of the author(s) and not those of the institute. Research disseminated by IZA may include views on policy, but the institute itself takes no institutional policy positions.

The Institute for the Study of Labor (IZA) in Bonn is a local and virtual international research center and a place of communication between science, politics and business. IZA is an independent nonprofit company supported by Deutsche Post World Net. The center is associated with the University of Bonn and offers a stimulating research environment through its research networks, research support, and visitors and doctoral programs. IZA engages in (i) original and internationally competitive research in all fields of labor economics, (ii) development of policy concepts, and (iii) dissemination of research results and concepts to the interested public.

IZA Discussion Papers often represent preliminary work and are circulated to encourage discussion. Citation of such a paper should account for its provisional character. A revised version may be available directly from the author. 


\section{ABSTRACT}

\section{Reducing Income Transfers to Refugee Immigrants: Does Starthelp Help You Start?*}

In this paper we estimate the causal effect of lowering the public income transfers administered to newly arrived refugee immigrants in Denmark - the so-called starthelp using a competing risk mixed proportional hazard framework. The two competing risks are exit to job and exit out of the labour force. A standard search model predicts that lower benefits decrease the reservation wage and/or increase the search effort. However, newly arrived refugee immigrants may initially have a weak position in the labour market due to the fact that they do not know the language and typically have no education, or alternatively, their education is not recognized in Denmark. Hence, there may be no demand for their skills. The empirical question addressed here is whether lower benefits affect their job finding rate; if no employer wants to hire them at the going minimum wage, the fact that the reservation wage is lowered may have little effect. For identification we use a 'quasi-natural' experiment, in which the rules for welfare benefits in Denmark changed rather dramatically. Refugee immigrants obtaining residence permit before July 1 st 2002 received and continue to receive larger income transfers than those obtaining their residence permit after July 1st. We find that lowering public income transfers has a small positive effect on the job finding rate, once calendar time effects are introduced into the model. However, introducing time-variation in the effect, we find that most of the positive effect stems from a large positive effect after two years in Denmark. We also find that the exit rate from the labour force is positively affected by lower transfers, but here the effect is large during the first year in the host country, and then it declines. Furthermore, we investigate heterogeneous treatment effects, and we find, generally, that those which we consider the weakest in the labour market are close to being immune to this treatment.

JEL Classification: E64, J18, J23, J38, J58, J65, J68

Keywords: economic incentives, refugee immigrants, duration model, quasi-natural experiment

Corresponding author:

Michael Rosholm

Department of Economics

Aarhus School of Business

University of Aarhus

Prismet, Silkeborgvej 2

8000 Aarhus C

Denmark

E-mail: rom@asb.dk

\footnotetext{
*We are grateful to The Danish Institute of Governmental Research (AKF), and to Leif Husted in particular, for providing the data. We appreciate comments from Peter Jensen, Maria Humlum and seminar participants at DGPE, Copenhagen Business School, and the National Directorate of Labour. The usual disclaimer applies.
} 


\section{Introduction}

In this paper we estimate the causal effect of lowering transfer payments on the job finding rates and exit rates out of the workforce for newly arrived refugee immigrants to Denmark. The source of exogenous variation we will use to identify this causal effect comes under the heading of a 'quasi-natural experiment'; in July 2002, the rules were changed such that social welfare transfers to newly arrived refugee immigrants was reduced by approximately $35 \%$, i.e. from approximately $€ 1200$ per month to approximately $€ 750$ per month $^{1}$. This lower transfer level was popularly labeled 'starthelp' and it replaced ordinary 'social assistance'. ${ }^{2}$ Those who obtained a residence permit before that date would still receive the higher social assistance payments, also after July 1st, 2002. Imposing an assumption of e.g. proportional hazards allows us to identify the effect of starthelp on transition rates separately from calendar time effects, due to within-half-year variation in arrival times. We use the term control group for the immigrants obtaining their residence permit before July 1st and the term treatment group for those obtaining their permit after July 1st.

The paper thus contributes to the sparse literature on the impacts of integration policies for refugee immigrants on labour market assimilation rates as well as the extensive literature on incentive effects of public income transfers.

According to standard search theory, a reduction in public income transfers leads to a reduction in reservation wages and/or an increase in job search intensity. Therefore such a reduction is perceived to shorten the time individuals spend searching for jobs, see e.g. Mortensen (1977). In empirical studies, this fairly clear-cut theoretical prediction has been verified in many studies on American as well as European data, see e.g. Bover et a. (2002), Abbring et al. (2005) (they look at sanctions), Carling et al (2001), Van Ours \& Vodopivec (2004, 2006), Lalive \& Zweimüller (2004), but it has occasionally been disputed, see e.g Bennmarker et al. (2005). Røed \& Zhang (2005) find a positive effect on job finding rates, but they also find a large positive effect on labour market exit rates.

The difficulty in obtaining evidence lies in identifying sufficient exogenous variation in benefit levels or replacement rates, and may partly be caused by short term economic incentives (welfare transfers versus starting wages in a firm) not being precise measures of economic incentives (or lack thereof); workers may even find it optimal to forego some income in the short run in order to gain a foothold in the labour market. There is also some evidence that the 'mental costs' of unemployment are quite large, see e.g. Van Praag \& Ferrer-i-Carbonell (2002). There is also an increasing awareness that perhaps the impact of lowering income transfers is heterogeneous in the sense that it affects different types of workers differently, see e.g. Strøm (1998) and Pedersen \& Smith (2002). Rosholm \& Toomet (2005) provide a theoretical model which has this prediction. In their model individuals with bad prospects in the labour market, i.e. those with low job offer

\footnotetext{
${ }^{1}$ These numbers refer to the transfers per month in 2006 to a single person aged above 25 with no children, and they are pre-tax transfers.

${ }^{2}$ Formally, the name of the income transfer was 'introductory payment at the level of starthelp'. We shall use the term 'starthelp' in this paper, although it is not formally correct.
} 
arrival rates, will react to a lowering of the transfer income by leaving the labour market rather than intensifying their search efforts. One may speculate, for example, that newly arrived refugee immigrants have qualification levels that are so low that they have difficulties finding employment at the going minimum wage: They do not know the Danish language, a large group among them are illiterate, most of those who have a formal education cannot use it in Denmark because educations taken outside EU are not recognized, the cultural span from labour market operations in their home country to those of Denmark are extremely large, etc. Of course, these workers may still react to lower income transfers by reducing their reservation wage and increasing their search efforts, but if demand for their work is low due to their lack of qualifications that are in demand by Danish employers, then even a positive behavioral response may never affect their job finding rate. In other words, in this particular case, there may be demand as well as supply constraints, and these may interfere with the 'pure' impacts of the economic incentives.

Finally, it is also obvious that if searching for a job becomes less attractive, due to the lowering of social transfers, then all alternatives become relatively more attractive, including employment but also various forms of non-participation. Hence, we may observe effects on transition rates in more than one direction.

On the other hand, a number of studies, most recently Constant \& Schultz-Nielsen (2004), show that immigrants lack economic incentives to work. For example, 33-41\% of the immigrants in the labour force gain (or would gain) less than $€ 100$ per month from working.

The impliction of this discussion is that the effect of lower transfer incomes is an empirical question.

In this paper, we ignore the calculation of specific economic incentives, acknowledging that exact 'incentives' depend on things other than current payments, and move directly to estimation of a causal relation between the level of gross welfare payments received and the transition rates into employment and non-participation. This is facilitated by the access to 'quasi experimental data', which ensures some exogenous variation in the levels of payments.

The Ministry of Integration (2005) compares two groups, those that immigrate from the 3. quarter of 2001 - 2. quarter 2002 to those immigrating from the 3 quarter 2002 - 2. quarter 2004, and they condition on the duration of stay in Denmark. They find that among those receiving starthelp, 36\% were no longer dependent on public transfers (or were receiving an education grant) after 2 years in Denmark. On the other hand, among those receiving social assistance, only $27 \%$ did no longer receive public income transfers. Their analysis is based on the so-called DREAM data set which contains spells of public income transfers of different types obtained from various sources. The reliability of this data set is normally considered high, although it only records exit from public income transfers, not the destination state (employment or non-participation). The implicit identification strategy is the assumption of a natural experiment. However, the treatment and control groups are not identical with respect to even basic characteristics such as gender, age, and country of origin. The treatment and control group that are compared can differ by almost three years in arrival date, so there is a possibility that the two groups face completely different 
labour markets. Moreover, calendar time effects (e.g. cyclical variations and trends stemming from other policy changes) are completely ignored. Another problem in this study is that they condition on receipt of a public income transfer. This generates a new selection problem in the sense that selection into the public income transfer system is endogenously determined by the level of payments. A final problem is the lack of ability to distinguish between different destination states. Exits out of public income transfers are all treated as successes, although some of them may be transitions into non-participation. However, this is the study which - together with quarterly updates of it - has generated the perceived wisdom that the starthelp is an enormous success.

The data set that we use contains information on all refugee immigrants coming to Denmark, but we will mostly limit ourselves to analyses based only on those refugee immigrants who obtain their residence permit in 2002. The data set is generated by combining information from many administrative registers and can thus be considered fairly reliable.

The dependent variable in this study is the length of time spent on starthelp or social assistance, before exit to the destination state. We define the destination state as being either 'employment' or 'non-participation', where 'non-participation' means not getting any temporary public income transfers and not having a job. We are able - to some extent - to distinguish between emigrating and being 'non-participant'.

Methodologically, we exploit the quasi-experimental nature of the 'starthelp' reform to identify and estimate an 'average effect of treatment on the treated' parameter. Since the treatment group consists of all refugee immigrants, this is also an average treatment effect in the population of refugee immigrants (as well as a local average treatment effect). In order to take into account that the composition of refugee immigrants may differ between the two half-years of 2002, we estimate parametric duration models, thereby also taking into account also dynamic selection bias and spurious duration dependence.

We find that, after the inclusion of calendar time effects, there is a positive effect on the exit rate to employment, but it is only significant in the interval $\frac{1}{2}-1$ year and again after 2 years in Denmark. The latter effect is by far the largest. Also, the effect on exit to 'non-participation' is positive, but here the effect is highest in the first year in Denmark. If calendar time effects are ignored, we find strong impacts in both directions, but the impact on exit to employment is now highest in the first year in Denmark. However, these impacts are spurious in the sense that they are generated by the missing calendar time. This is discussed in detail in the paper.

The remainder of the paper is organized as follows; the next section briefly reviews the main institutional settings surrounding immigration to Denmark. Section 3 describes the data set used in the study. Section 4 presents econometric methodology, model parameterization, our identification strategy, and the basic assumptions made. It also discusses the nature of the estimated parameters. Section 5 discusses the results obtained when ignoring calendar time effects, while section 6 present our main results, which include calendar time effects. Heterogeneous treatment effects are considered in section 7. Unobserved heterogeneity is taken into account in section 8 , and robustness of the results is discussed in section 9 , while section 10 contains a conclusion and 
some policy recommendations.

\section{Institutional settings}

In this section we describe the institutional setting that refugee immigrants face when they arrive in Denmark. There are two ways of obtaining asylum in Denmark. The first way is so-called spontaneous asylum seekers, who come to Denmark and apply for asylum. When arriving in Denmark persons without a residence permit can apply for asylum by contacting the Danish authorities. The Danish Immigration Service then investigates whether there are grounds for granting asylum. This process can take a long time, and during the process the asylum seeker stays at an asylum centre. If the Danish Immigration Service decides not to grant asylum the asylum seeker has some possibilities to appeal, but if the ruling stands the asylum seeker has to leave Denmark. If the Danish Immigration Service grants asylum the refugee gets a residence permit. Asylum can be granted to spontaneous asylum seekers based on different foundations. There are three main groups. The first group is granted asylum based on the United Nations 1951 Refugee Convention which Denmark has signed. The second group is granted asylum based on criteria broader than those in the Refugee Convention. These refugees are called De Facto refugees $^{3}$. The third group is a residual group, which mainly consists of refugees who are given residence permits for 'humanitarian reasons'.

The second way of getting asylum is to be offered re-settlement in Denmark. These are the socalled Quota refugees or UN refugees. Since 1978 the Danish government has each year committed to giving asylum to a certain number of refugees - primarily from the UN refugee camps around the world. The refugees who get the offer of re-settlement in Denmark are selected on travels to selected refugee camps made by emplyees at the Danish Immigration Service each year ${ }^{4}$. Usually the Immigration Service make two to four such travels each year. The refugees who are offered re-settlement arrive in Denmark within the following one to six months.

Upon obtaining their residence permits the refugees are dispersed to the municipalities by the Danish Immigration Service, which tries to reach a fairly even geographical dispersion of refugees, although personal conditions are also taken into account ${ }^{5}$. The municipalities have an obligation to offer an Introduction Program which should last at most 3 years. The Introduction Program consists of Danish language courses and labor market related training activities, i.e. upgrading of skills, vocational training, temporary jobs in the public sector etc. The Danish language courses have three levels. Level one is for refugees with no reading and writing skills in their mother tongue. Level two is for refugees with short schooling levels from their home country. Level three

\footnotetext{
${ }^{3}$ The De Facto rules were tightened dramatically on July 1st 2002, but the rules were changed such that they took effect based on the date of asylum application, whereas the rules of starthelp took effect based on the date of the residence permit. There are very few individuals in our study who have been granted asylum based on the new rules, so we do not regard this as a problem.

${ }^{4} \mathrm{http}$ // www.nyidanmark.dk/en-us/coming_to_dk/asylum/quota_refugees.htm

${ }^{5} \mathrm{http}: / /$ www.nyidanmark.dk/da-dk/Integration/integration_af_nyankomne/boligplacering_af_flygtninge.htm
} 
is for refugees with middle or longer levels of schooling. For further information, see Clausen et al. (2006). If the immigrant got the residence permit before July 1st $2002 \mathrm{~s} /$ he would be entitled to Social Assistence, while if the immigrant got the residence permit after this date s/he would be entitled to the lower 'starthelp'.

\section{Data}

The data set used in this study is based on two panel data sets. The first contains all immigrants in Denmark and are administrative register-based data observed on an annual basis from 1984 to 2004. This data set contains information on different demographic and individual characteristics such as gender, age, number of children, date of latest immigration, country of origin, family status, public transfers etc. The second data set is also based on administrative registers, and it contains monthly information from January 1984 to December 2004 on whether the person observed is employed or receives public income transfers or if the person is outside the labour market. If public income transfers are received then the type of transfer is also included. The administrative registers used for the generation of this event history are registers on mandatory pension payments made by employers (ATP-CON), on registered public income transfer payments made to individuals and the types of payments (Sammenhængende Socialstatistik-SHS), on registered unemployment (CRAM) and program participation (AMFORA). This implies quite a few cross-validation possibilities, and the data are therefore considered very reliable.

From the combined panel data set, we select all refugee immigrants who have an immigration date in 2002. This is done by selecting the immigrants who received their permanent residence permit by being granted asylum, which is also the immigration date. This data set contains 2,567 refugee immigrants. ${ }^{6}$

We then remove those who had an earlier registered immigration date (after 1984), i.e. we remove the refugee immigrants who have been in the country before. This is done since we are interested in the effect of starthelp on first time refugee immigrants and not on immigrants who already have an association with Denmark and possibly the Danish labor market. This leaves us with 2,523 refugee immigrants.

Since we are interested in transitions from a public income transfer - starthelp - to employment and education we have to restrict the sample population even further. We select those who are aged between 18 and 65. This is 1,728 individuals of whom 924 immigrated in the first half of 2002 and 804 immigrated in the second half. For each individual we have a monthly event history file from the month of immigration until the end of 2004.

When an immigrant receives the residence permit the person is offered 'starthelp' or 'social assistance', so 'receipt of temporary income support' is in principle always the initial state occupied

\footnotetext{
${ }^{6}$ Some individuals who are family re-unified to refugee immigrants are also eligible for starthelp. However, for some reason these individuals are difficult to distinguish from other groups in this sample. This is briefly discussed in section 9 .
} 
by refugee immigrants. However, there are a few who never receive starthelp or social assistance. Since this is an endogenous event, these individuals are assigned an exit in the first month, that is, a duration in this state which is shorther than one month. We then define an exit from the state of 'temporary income support' if we do not observe any income transfer payments for 2 successive months ${ }^{7}$. Exit can occur into two competing states, the first called 'Employment', and the second residual state called 'Out' which is short for 'non-participation'.

An exit to the Employment state is defined to have taken place if the person under observation is employed as either regular employee, self-employed or assisting spouse in two successive months immediately after leaving the public income transfer system or if $\mathrm{s} /$ he receives educational subsidies for two successive months. ${ }^{8}$ If the immigrant has a defined exit from the initial state and it is not into the state Employment, then we define this as an exit into 'Out'. The state 'Out' consists of some individuals receiving other income transfers than starthelp or social assistance (such as pension benefits, early retirement benefits etc.), ${ }^{9}$ some receiving no income transfers but who are not working either, and presumably some who have left the country temporarily or permanently without informing the authorities. When refugees emigrate from Denmark they should ideally inform the authorities. However, we suspect that this does not always happen, and hence we cannot be certain that exits to 'Out' do not consist of at least some persons who have emigrated.

It must be noted that - during the validation phase of the study - we discovered a number of discrepancies with respect to another data set which has been used extensively for the analysis of the effect of starthelp, namely the so-called DREAM data set, maintained by the Danish labour market board (Arbejdsmarkedsstyrelsen, AMS). We observed a number of individuals who, according to DREAM, stopped receiving public income transfers (starthelp or social assistance), but who according to our data did not stop receiving the same income transfers during the observation period (until the end of 2003). We have checked this all the way down into the raw data source of our own event histories (i.e. the SHS-register), and our event histories are consistent with the raw data in this respect. Hence, as the information in this register is based on actual payments registered, we consider it the most reliable data source.

Moreover, there is a problem with the registration of emigration of refugees. We observe a total of 73 refugees who emigrate again, but the emigration is clustered in January 2003 and 2004, where we observe 43 emigrations in January 2003 and 21 in January 2004. In January 200322 of the 43 are from the treatment group and in January 200413 of the 21 are from the treatment group. These observations are all being right censored in the analysis below, since we do not believe that they have all emigrated exactly in January. If left unaccounted for this would lead to an upward biased estimate of the treatment effect on the state Out.

In January 2003 we also correct 64 exits to Out of whom 61 are from the treatment group,

\footnotetext{
${ }^{7}$ We have performed the analyses with both 1 and 3 months and it makes very little difference.

${ }^{8}$ Around $1 \%$ exits to education and we have chosen to include these with the Employment state, since starting an education is considered a positive outcome.

${ }^{9} 1-2 \%$ of the spells ended in exit from starthelp to rehabilitation, early retirement, disability payment and the like (See Table 1)
} 
where there are no registered public transfers for a period of varying length, and then later we observe a re-entry into starthelp or social assistance. For most of these individuals, the re-entry takes place within a few months after January 2003. Taking a closer look at the payment amounts registered, it is obvious that the registration of payments are made in batches, as the payment made for a typical person in e.g. April corresponds identically to three months of the monthly payment to which the person is entitled. When this is the case, we fill in the blank months with receipt of the relevant payment. To be consistent we also apply this method to January 2004 and this results in a correction of 8 observations of whom 6 were controls. This suggests that there may have been some problems in the beginning of 2003 in deciding how to register starthelp income transfers. We have not been able to obtain more information on this issue. However, if it is neglected, there would have been a huge outflow from the treatment group to 'Out' in January 2003, which would lead to an upward bias in our estimated treatment effects.

There is a similar problem with the data when the refugee immigrants have just arrived. For some individuals there is a span of time between arrival and the first payment registered. This results in many exits the first month if we do not correct for it. We have chosen to correct for it by filling in all blank initial periods with the public income transfer receipt if the blank period was followed by public income transfer receipt within three months after arrival. This choice will be discussed further in the robustness section. Table 1 contains descriptive statistics for the treatment and control group. ${ }^{10}$

\footnotetext{
${ }^{10}$ Controls measured in June 2004 and treatments in December 2004 in order to normalize the amount of time spent in Denmark.
} 
Table 1: Descriptive statistics for refugee immigrants 2002

\begin{tabular}{|c|c|c|}
\hline & $\begin{array}{l}\text { Immigrated } \\
\text { before } 1 / 7-2002\end{array}$ & $\begin{array}{l}\text { Immigrated } \\
\text { after } 1 / 7-2002\end{array}$ \\
\hline & CONTROLS & TREATMENTS \\
\hline Final population & 924 & 804 \\
\hline Exits to Employment & 21.5 & 28.1 \\
\hline Exits to Out & 9.3 & 11.6 \\
\hline - of which were other public income transfers & 1.7 & 1.4 \\
\hline \multicolumn{3}{|l|}{ Demographic characteristics } \\
\hline Has children (\%) & 39.8 & 38.4 \\
\hline Female $(\%)$ & 33.9 & 37.8 \\
\hline Aged 18-29 (\%) & 35.6 & 40.9 \\
\hline Aged 30-39 (\%) & 38.1 & 38.6 \\
\hline Aged 40-49 (\%) & 17.6 & 15.4 \\
\hline Aged above $50(\%)$ & 8.7 & 5.1 \\
\hline \multicolumn{3}{|l|}{ Reason for asylum } \\
\hline - Quota system & 3.9 & 23.8 \\
\hline - Convention refugee & 14.9 & 22.4 \\
\hline - De facto refugee & 63.6 & 39.8 \\
\hline - Rest & 17.6 & 14.0 \\
\hline \multicolumn{3}{|l|}{ Country of origin } \\
\hline - Iran & 3.4 & 16.5 \\
\hline - Iraq & 36.5 & 22.5 \\
\hline - Somalia & 12.9 & 18.4 \\
\hline - Bosnia/Herzegovina & 8.5 & 8.6 \\
\hline - Former Yugoslavia & 10.7 & 4.9 \\
\hline - Afghanistan & 8.0 & 7.7 \\
\hline \multicolumn{3}{|l|}{ Region of Residence } \\
\hline Copenhagen & 2.3 & 2.0 \\
\hline Zealand, excl. Copenhagen & 37.4 & 34.8 \\
\hline Funen & 9.7 & 10.7 \\
\hline Jutland & 50.5 & 52.5 \\
\hline \multicolumn{3}{|l|}{ Starting schooling level } \\
\hline School 1 & 20.5 & 14.9 \\
\hline School 2 & 38.5 & 41.3 \\
\hline School 3 & 27.3 & 26.7 \\
\hline Never attended school & 13.7 & 17.1 \\
\hline
\end{tabular}

First of all, the group that immigrated in the first half-year of 2002 - the controls - seems to be finding employment at a lower rate than those immigrating in the second half-year - the treatments. The same appears to be the case for exits to the state 'Out' but at a lower rate. Hence, this is the first indication that the introduction of starthelp had an impact on the transition patterns of the affected individuals.

Secondly, it is immediately obvious that a pure experimental strategy of comparing means 
between the two groups is not appropriate. There are large differences in characteristics between the two groups. The treatments are slightly younger than the controls and more of them are women. Moreover, the treatment group consists of more Iranians and Somalis than the controls, where there is a very large group of refugees from Iraq. There are more Quota and Convention refugees in the treatment group. The schooling levels in Table 1 are the levels in the language courses that the refugees start on when participating in the Introduction Program. ${ }^{11}$ The control groups has a larger group of illiterates, while the treatment group has a larger group of individuals who never attend language training. The region of residence refers to the initial location of the refugees. This location is exogenous, since Denmark has a dispersal policy for refugees.

\section{Identification and the econometric model}

\subsection{Identification}

The quasi-experiment as described above does not provide us with non-parametric identification of the parameters of interest; the treatment effect. There is the possibility that the results will be influenced by calendar time effects that occur due to business cycle conditions, general time trends, or other reforms affecting the outcome. Such calendar time effects may seriously bias the results if they are unaccounted for. The problem is that a general calendar time effect will affect the treatments at an earlier stage of their duration than the controls, as they have on average arrived 6 months later than the control group. Assuming that the calender time effect is growing over time this would lead to an upward bias in the treatment parameters.

It is therefore impossible to identify any treatment effect parameters in a non-parametric way. There are - in our view - basically two ways out of this problem. First, one could use a kind of regression discontinuity design, i.e. using the refugees arriving one month before and one month after July 1st, and then making the argument that these are so close in time that there are no general calender time effects and no differences in their baseline. This would give us a nonparametric way to identify parameters of interest. The problem with this approach is that we have very few observations each month and that there are differences in the observed characteristics of those who arrive in different months. The second possibility is to assume some kind of functional form for the calender time effect. This would identify the parameters of interest up to the functional form assumption.

We have chosen the second approach and used a mixed proportional hazard (MPH) competing risks model, since this yields two advantages. First, if we use calender time dummies we can identify calender time effects which we argue capture things such as business cycle conditions, general time trends, or other reforms affecting the outcome. Second, it gives us the possibility of controlling for observed and unobserved heterogeneity.

\footnotetext{
${ }^{11}$ We have here used the starting level. There are data for weekly levels, but these data only covers the period until ultimo 2003. We have tried to use time-varying levels were it was possible but this made no difference.
} 


\subsection{The Econometric model}

In this section we specify the econometric model used to investigate how starthelp affects the transitions in the labor market. We assume that the refugee immigrants, when receiving their residence permits, start as 'recipients of temporary income transfers' and therefore they receive an income transfer, which is either starthelp (the treatments) or social assistance (the controls).

There are two exit states for refugee immigrants receiving one of these income transfers, which is Employment, $j$, and a state called Out, $o$. Let $T_{u}$ be a random variable which denotes the observed duration of time from the date of immigration until exit from the initial state of transfer income receipt, that is, $T_{u}=\min \left(T_{j}, T_{o}, C\right)$, where $T_{j}$ is a latent random variable denoting the time until exit to Employment. $T_{o}$ is defined accordingly for transitions into the state Out. $C$ denotes the time until right censoring. We assume that these three random variables are independent given observed and unobserved characteristics.

We specify a competing risks model where the transition rates are assumed to be mixed proportional hazards, that is,

$$
\theta_{i}\left(t \mid x_{i t}, \tau, d, v_{i}\right)=\lambda_{i}(t) \cdot \omega_{i}\left(\tau_{t}\right) \cdot \phi_{i}\left(x_{i t}, d\right) \cdot v_{i}=\lambda_{i}(t) \cdot \omega_{i}\left(\tau_{t}\right) \cdot \exp \left(x_{i t}^{\prime} \beta+d \gamma_{t}+v_{i}\right)
$$

where $i=j, o, \lambda_{i}(t)$ is the baseline hazard, $\omega_{i}\left(\tau_{t}\right)$ is the calendar time effect $\left(\tau_{t}\right.$ denotes calendar time at time $t, \tau_{t}=\tau_{0}+t$, where $\tau_{0}$ is the immigration date), $x_{i t}$ are potentially time-varying observed characteristics, $d$ is a dummy for treatment and $v_{i}$ is a scalar unobserved component. Note that we have allowed for duration specific treatment effects. The baseline hazards will be flexibly specified.

The contribution to the likelihood function for a single individual, given observed and unobserved characteristics, is

$$
\begin{aligned}
\mathcal{L}\left(\boldsymbol{\varphi} ; v_{j}, v_{o}\right)= & \theta_{j}\left(t_{u} \mid x_{j t}, \tau_{t}, d, v_{j}\right)^{1\left\{T_{j}<\min \left(T_{o}, C\right)\right\}} \cdot \theta_{o}\left(t_{u} \mid x_{o t}, \tau_{t}, d, v_{o}\right)^{1\left\{T_{o}<\min \left(T_{j}, C\right)\right\}} \\
& \times \exp \left[-\int_{0}^{t_{u}} \theta_{j}\left(s \mid x_{j s}, \tau_{s}, d, v_{j}\right) d s-\int_{0}^{t_{u}} \theta_{o}\left(s \mid x_{o s}, \tau_{s}, d, v_{o}\right) d s\right]
\end{aligned}
$$

where $\varphi$ denotes all parameters to be estimated by the model. Since we do not observe $v$, but under the standard assumption in random effects models of independence between $x$ and $v$, we can integrate it out of the likelihood function, such that the likelihood contribution conditional only on observed characteristics is

$$
\mathcal{L}(\boldsymbol{\varphi})=\iint \mathcal{L}\left(\boldsymbol{\varphi} ; v_{j}, v_{o}\right) d G\left(v_{j}, v_{o}\right)
$$

The parameter $\gamma$ can be interpreted as an average treatment effect (ATE). The reason is that we assign those individuals who do not enter the initial state of income transfer receipt an exit in the first month, in order to avoid selective sampling. Conditioning on receipt of public income 
transfers would lead to sample selection problems, as discussed in the introduction. Since the fraction that leaves the initial state in the first period - and therefore does not get the actual treatment - is very small, the ATE is almost the same as the average treatment effect on the treated, where treated here refers to actually receiving the lower benefits.

The model is identified given two assumptions, see Abbring \& Van den Berg (2003b);

(i) There is variation with the observed regressors;

$\left\{\left(\phi\left(x_{j t}\right), \phi\left(x_{o t}\right)\right): x \in X\right\}$ contains a non-empty open set $\Phi \subset R^{2}$, where $X$ is the support of $x$.

(ii) The mean of the mixing distribution is finite;

$E\left(v_{i}\right)<\infty$ for $i=(j, o)$

Calendar time effects are identified from their variation across individuals with different immigration dates, which is something that the duration approach allows for in contrast to binary models.

The identification argument of the unobserved heterogeneity goes loosely as follows: Hold the influence of the observed regressors on exit to Employment, $\phi_{e}\left(x_{e t}\right)$, at a given level while varying $x$. Since the regressors have different influences on exit to Employment and Out, changing the regressors will change the exit rate to Out and thereby change the composition of the potentially joint unobserved heterogeneity. If there is no joint unobserved heterogeneity there will be no effect from this exercise since the only effect is through the joint distribution of $v_{i}$ given $\mathrm{x}$. This is informative about the effect of unobserved heterogeneity on the hazard to Employment. For a formal treatment see Abbring \& van den Berg (2003b) or Xinghua (2006). Xinghua (2006) extends Abbring \& van den Berg (2003b) to account for time-varying covariates.

There are two important concerns with our identification strategy. First, we have made a functional assumption implying that the effect of being in a certain month is the same for all individuals. This is an identifying assumption and therefore it cannot be tested. However, since we have plenty of variation in arrival times - individuals may arrive in one of 12 months during 2002 - there is sufficient variation in the data to identify calendar time effects, baseline hazards, and treatment effects, given the identifying assumption of proportional hazards. In the result section below, we first report the results where calendar time effects are ignored. However, as the results turn out to change dramatically once calendar time effects are included, we subsequently report the results from estimations taking calendar time effects into account. The robustness of the results with respect to the identifying assumption and the calender time effect is discussed further in section 9 .

The second concern is that there are some systematic differences between the control and the treatment group. We argue that - due to the fact that the rule change was not anticipated by the refugee immigrants when applying for asylum - there is no systematic differences in unobserved characteristics due to self-selection into arrival times. However, other institutional settings, such as the 'best' quota refugees being picked in the first half year, could imply a difference in unobserved 
characteristics. To check this we estimate the model for the years 2001 and 2003 to make a simple check. This is also discussed in section 9 ..

\subsection{Parameterization}

We would like to make the parameterization as flexible as possible. We specify the baseline hazard to be very flexible, i.e.

$$
\lambda_{i}(t)=\exp \left[\sum_{m=1,2, \ldots} \lambda_{i m} I_{m}(t)\right] \quad i=j, o
$$

where $m$ is a subscript for time intervals and $I_{m}(t)$ is a time-varying dummy that takes the value 1 if $t \in m$.

Following Heckman \& Singer (1984) we specify the mixture distribution as a discrete distribution with two points of support for each of the marginal distributions of the unobserved variables. Let $v_{j}^{a}, v_{j}^{b}, v_{o}^{a}$ and $v_{o}^{b}$ be the points of support and let the associated probabilities be denoted

$$
\begin{aligned}
& p_{1}=\operatorname{Pr}\left(v_{j}=v_{j}^{a}, v_{o}=v_{o}^{a}\right) \\
& p_{2}=\operatorname{Pr}\left(v_{j}=v_{j}^{a}, v_{o}=v_{o}^{b}\right) \\
& p_{3}=\operatorname{Pr}\left(v_{j}=v_{j}^{b}, v_{o}=v_{o}^{a}\right) \\
& p_{4}=\operatorname{Pr}\left(v_{j}=v_{j}^{b}, v_{o}=v_{o}^{b}\right)
\end{aligned}
$$

with $0 \leq p_{i} \leq 1$ and $p_{4}=1-p_{3}-p_{2}-p_{1}$.

We normalize $v_{o}^{b}=v_{j}^{b}=0$ since the baseline hazard already has a constant term. The covariance of $v_{o}$ and $v_{j}$ then equals

$$
\operatorname{cov}\left(v_{o}, v_{j}\right)=\left(p_{1} p_{4}-p_{2} p_{3}\right) v_{j}^{a} v_{o}^{a}
$$

\section{$5 \quad$ Results without calendar time effects}

Let us first take a look at the raw data. Figure 1 plots the Kaplan-Meier hazard rates for the transition into employment for the treatment group and the control group. 
Figure 1: Kaplan-Meier transition rates into Employment

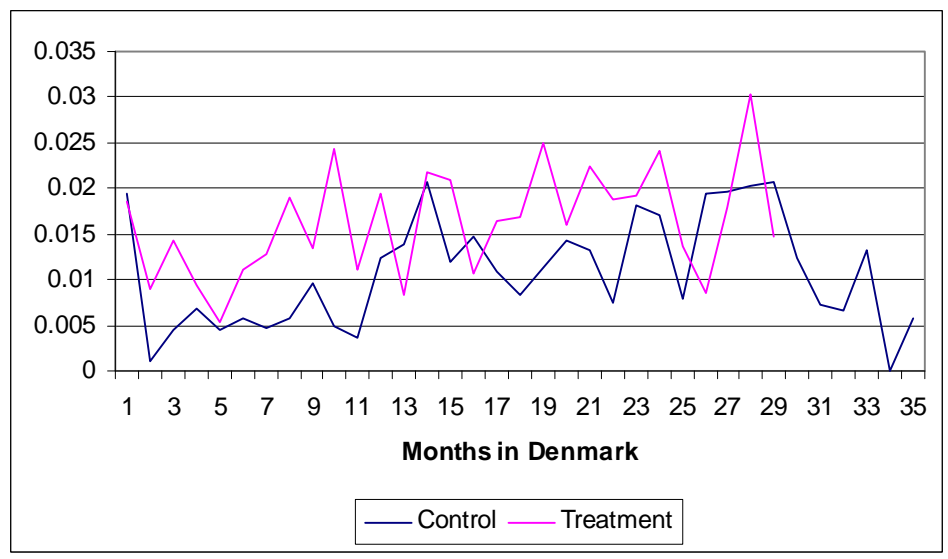

It is indeed seen, as was also suggested by the numbers in Table 1, that the exit rate to Employment is generally highest for those in the treatment group, although the picture is not completely uniform. Note that the transition rate is defined on a shorter interval for the treatment group than for the control group, since individuals are only followed until the end of 2004. Figure 2 shows the Kaplan-Meier transition rates into the state Out.

Figure 2: Kaplan-Meier transition rates into the state Out

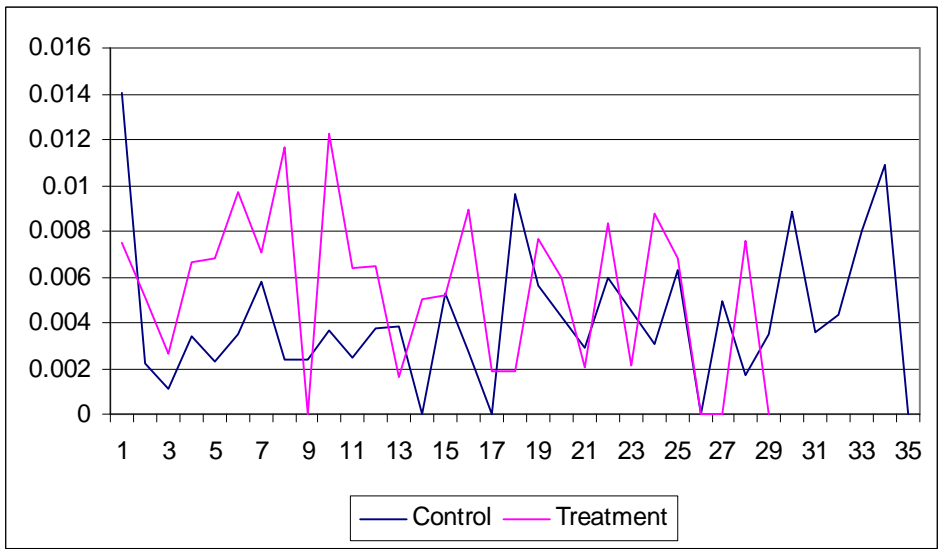

Here it is more difficult to get a clear idea, but the general pattern is also that the transition rate is a bit higher for those receiving starthelp.

However, as mentioned above, we have to condition on observed characteristics, so we now turn to the results from the duration model.

Table 2 reports the results from the estimation of various specifications of the model for exit into employment. Our strategy in choosing baseline intervals and also intervals for time-varying treatment effects as well as the calendar time intervals in the most flexible reported model (model 3 in tables 2 and 3) is general-to-specific using LR-tests. Hence, in obtaining model 3, we start with a completely flexible specification of the baseline hazard, calendar time effects, and treatment effects. 
Table 2: Estimation results for transition into Employment, no calendar time effects

\begin{tabular}{|c|c|c|c|c|c|c|}
\hline & \multicolumn{2}{|l|}{ Model 1} & \multicolumn{2}{|l|}{ Model 2} & \multicolumn{2}{|l|}{ Model 3} \\
\hline & Est. & Std. Err & Est. & Std. Err & Est. & Std. Err \\
\hline Treatment effects & & & & & & \\
\hline ATE & 0.427 & 0.101 & 0.574 & 0.106 & & \\
\hline ATE Month 1-12 & & & & & 0.698 & 0.155 \\
\hline ATE Month $13-30$ & & & & & 0.406 & 0.126 \\
\hline Baseline & & & & & & \\
\hline Month 1-36 & -3.170 & 0.356 & & & & \\
\hline Month 1 & & & & & -2.654 & 0.403 \\
\hline Month 2 & & & & & -3.952 & 0.503 \\
\hline Month 3-12 & & & & & -3.115 & 0.379 \\
\hline Month 13+ & & & & & -2.219 & 0.405 \\
\hline Month 1-3 & & & -2.962 & 0.391 & & \\
\hline Month 4-6 & & & -3.321 & 0.409 & & \\
\hline Month 7-9 & & & -2.877 & 0.393 & & \\
\hline Month 10-12 & & & -2.679 & 0.397 & & \\
\hline Month 13-15 & & & -2.319 & 0.412 & & \\
\hline Month 16-18 & & & -2.492 & 0.415 & & \\
\hline Month 19-21 & & & -2.195 & 0.419 & & \\
\hline Month 22-24 & & & -2.129 & 0.410 & & \\
\hline Month 25-27 & & & -2.039 & 0.423 & & \\
\hline Month 28-30 & & & -1.704 & 0.441 & & \\
\hline Month 31-33 & & & -2.248 & 0.493 & & \\
\hline Month 34-36 & & & -3.217 & 1.104 & & \\
\hline Covariates & & & & & & \\
\hline Quota refugee & -0.471 & 0.215 & -0.487 & 0.215 & -0.499 & 0.215 \\
\hline De Facto refugee & 0.047 & 0.126 & 0.038 & 0.127 & 0.036 & 0.127 \\
\hline Other refugee types & -0.122 & 0.197 & -0.126 & 0.199 & -0.139 & 0.199 \\
\hline Local unemployment rate in \% & 0.033 & 0.040 & -0.072 & 0.047 & -0.055 & 0.046 \\
\hline Age $30-39$ & -0.390 & 0.102 & -0.422 & 0.103 & -0.415 & 0.103 \\
\hline Age $40-49$ & -0.893 & 0.157 & -0.975 & 0.158 & -0.962 & 0.158 \\
\hline Age above 50 & -2.730 & 0.509 & -2.800 & 0.509 & -2.786 & 0.509 \\
\hline Female & -0.626 & 0.163 & -0.657 & 0.164 & -0.649 & 0.164 \\
\hline Has children & 0.095 & 0.214 & 0.114 & 0.215 & 0.110 & 0.215 \\
\hline Number of children & -0.039 & 0.064 & -0.033 & 0.065 & -0.034 & 0.064 \\
\hline Female*has children & -0.750 & 0.255 & -0.831 & 0.257 & -0.819 & 0.256 \\
\hline Married & 0.452 & 0.180 & 0.512 & 0.180 & 0.498 & 0.182 \\
\hline Spouse on transfer & -0.861 & 0.177 & -0.954 & 0.178 & -0.930 & 0.179 \\
\hline Somalia & -0.603 & 0.181 & -0.574 & 0.183 & -0.576 & 0.183 \\
\hline Afghanistan & 0.233 & 0.181 & 0.333 & 0.182 & 0.308 & 0.182 \\
\hline Iraq & -0.114 & 0.129 & -0.080 & 0.130 & -0.094 & 0.130 \\
\hline Iran & 0.042 & 0.225 & 0.063 & 0.224 & 0.062 & 0.225 \\
\hline Bosnia-Herzegov, & 0.556 & 0.201 & 0.620 & 0.200 & 0.609 & 0.201 \\
\hline Former Yugoslavia & -0.140 & 0.267 & -0.095 & 0.271 & -0.101 & 0.270 \\
\hline School level 1 & -0.865 & 0.197 & -0.956 & 0.197 & -0.945 & 0.198 \\
\hline School level 2 & -0.183 & 0.144 & -0.228 & 0.144 & -0.225 & 0.144 \\
\hline School level 3 & 0.133 & 0.149 & 0.090 & 0.151 & 0.092 & 0.151 \\
\hline Copenhagen & 1.021 & 0.256 & 0.959 & 0.258 & 0.955 & 0.258 \\
\hline Zealand, excl. Copenhagen & 0.038 & 0.106 & -0.038 & 0.108 & -0.023 & 0.108 \\
\hline Funen & 0.143 & 0.161 & 0.257 & 0.165 & 0.247 & 0.165 \\
\hline $\begin{array}{l}\text { Number of obs. } \\
\text { LogLikelihood }\end{array}$ & & $\begin{array}{r}1728 \\
-2566.36\end{array}$ & & $\begin{array}{r}1728 \\
-2529.56\end{array}$ & & $\begin{array}{r}1728 \\
-2521.14\end{array}$ \\
\hline
\end{tabular}

Note: Numbers in bold are statistically significant at the $5 \%$ level.

The first model reports the results, where the only included variable is the treatment indicator, 
a constant baseline and covariates. It shows that the transition rate into employment is approximately $53 \%(\exp [0.427]-1)$ higher - and statistically significant - for those in the treatment group. This is indicated by the ATE parameter. Turning to the individual-specific variables, we see that many of these variables are statistically significant in explaining the transition into employment. We see that Quota refugees have a lower transition rate than convention refugees, which constitute the reference group. Age has a strong negative influence on transitions into employment, especially for individuals aged above 50, where the transition rate is essentially 0 . Women have lower transition rates than men, especially if they have children. Individuals whose spouse also receives either social assistance or starthelp have much lower transition rates into employment than those whose spouses do not receive any income transfer of this type. ${ }^{12}$ Individuals from Somalia have much lower transition rates than the reference category of refugee immigrants from all other countries than those listed in the table, while persons from Bosnia-Herzegovina find employment at a somewhat faster rate than the remaining groups. The higher the schooling level, the higher the transition rate. Here the reference group is the group that did not attend language training, possibly because they found a job very quickly. Finally, individuals located in Copenhagen have higher transition rates into Employment.

The next set of results, denoted Model 2, includes a more flexible baseline specification. The baseline seems to be generally increasing but then falling in the last two quarters. The explanatory variables do not change much, while the ATE increases a bit. Looking at Model 3, which allows for time-varying treatment effects, we find that the starthelp effects are higher in the beginning of the spell.

Table 3 contains similar estimates for the transition into the state Out.

\footnotetext{
${ }^{12}$ We tried interactions with the treatment indicator, in order to see if spouses on starthelp had a different impact than spouses on social assistance, but the interaction was close to zero and insignificant.
} 
Table 3: Estimation results for transition into state Out, no calendar time effects

\begin{tabular}{|c|c|c|c|c|c|c|}
\hline & \multicolumn{2}{|l|}{ Model 1} & \multicolumn{2}{|l|}{ |Model 2} & \multicolumn{2}{|l|}{ Model 3} \\
\hline & Est. & Std. Err & Est. & Std. Err & Est. & Std. Err \\
\hline Treatment effects & & & & & & \\
\hline ATE & 0.201 & 0.162 & 0.259 & 0.170 & & \\
\hline ATE Month 1-12 & & & & & 0.425 & 0.262 \\
\hline ATE Month $13-30$ & & & & & -0.016 & 0.207 \\
\hline Baseline & & & & & & \\
\hline Month 1-36 & -5.611 & 0.552 & & & & \\
\hline Month 1 & & & & & -5.175 & 0.611 \\
\hline Month 2-17 & & & & & -5.844 & 0.569 \\
\hline Month 18+ & & & & & -5.427 & 0.607 \\
\hline Month 1-3 & & & -5.602 & 0.574 & & \\
\hline Month 4-6 & & & -5.578 & 0.574 & & \\
\hline Month 7-9 & & & -5.629 & 0.611 & & \\
\hline Month $10-12$ & & & -5.450 & 0.617 & & \\
\hline Month 13-15 & & & -5.919 & 0.641 & & \\
\hline Month 16-18 & & & -5.682 & 0.654 & & \\
\hline Month 19-21 & & & -5.568 & 0.649 & & \\
\hline Month 22-24 & & & -5.456 & 0.633 & & \\
\hline Month 25-27 & & & -5.734 & 0.725 & & \\
\hline Month 28-30 & & & -5.438 & 0.679 & & \\
\hline Month 31-33 & & & -5.047 & 0.713 & & \\
\hline Month 34-36 & & & -4.417 & 0.851 & & \\
\hline Covariates & & & & & & \\
\hline Quota refugee & 0.127 & 0.319 & 0.114 & 0.320 & 0.116 & 0.318 \\
\hline De Facto refugee & -0.194 & 0.212 & -0.194 & 0.213 & -0.186 & 0.212 \\
\hline Other refugee types & -0.148 & 0.336 & -0.149 & 0.337 & -0.140 & 0.334 \\
\hline Local unemployment rate in \% & 0.111 & 0.053 & 0.102 & 0.062 & 0.114 & 0.060 \\
\hline Age 30-39 & -0.601 & 0.177 & -0.611 & 0.178 & -0.606 & 0.177 \\
\hline Age $40-49$ & -0.982 & 0.274 & -1.001 & 0.276 & -1.001 & 0.275 \\
\hline Age above 50 & -0.138 & 0.248 & -0.149 & 0.250 & -0.148 & 0.248 \\
\hline Female & 0.427 & 0.210 & 0.429 & 0.210 & 0.432 & 0.208 \\
\hline Has children & -0.300 & 0.419 & -0.287 & 0.419 & -0.299 & 0.417 \\
\hline Number of children & -0.114 & 0.135 & -0.114 & 0.136 & -0.115 & 0.136 \\
\hline Female*has children & -0.188 & 0.353 & -0.210 & 0.357 & -0.203 & 0.353 \\
\hline Married & 1.440 & 0.245 & 1.428 & 0.247 & 1.394 & 0.246 \\
\hline Spouse on transfer & -1.619 & 0.242 & -1.601 & 0.246 & -1.554 & 0.244 \\
\hline Somalia & 0.408 & 0.296 & 0.417 & 0.296 & 0.401 & 0.294 \\
\hline Afghanistan & 0.679 & 0.344 & 0.680 & 0.342 & 0.668 & 0.340 \\
\hline Iraq & 0.486 & 0.262 & 0.477 & 0.263 & 0.472 & 0.261 \\
\hline Iran & 0.391 & 0.354 & 0.405 & 0.355 & 0.399 & 0.350 \\
\hline Bosnia-Herzegov, & 0.157 & 0.372 & 0.156 & 0.374 & 0.130 & 0.371 \\
\hline Former Yugoslavia & 0.032 & 0.400 & 0.027 & 0.401 & 0.014 & 0.396 \\
\hline School level 1 & -1.115 & 0.255 & -1.130 & 0.257 & -1.120 & 0.255 \\
\hline School level 2 & -0.927 & 0.222 & -0.938 & 0.222 & -0.923 & 0.221 \\
\hline School level 3 & -0.766 & 0.229 & -0.765 & 0.228 & -0.759 & 0.228 \\
\hline Copenhagen & 0.995 & 0.423 & 1.018 & 0.421 & 1.034 & 0.410 \\
\hline Zealand, excl. Copenhagen & -0.299 & 0.174 & -0.304 & 0.173 & -0.296 & 0.173 \\
\hline Funen & -0.182 & 0.254 & -0.168 & 0.255 & -0.184 & 0.254 \\
\hline $\begin{array}{l}\text { Number of obs. } \\
\text { LogLikelihood }\end{array}$ & & $\begin{array}{r}1728 \\
-1136.48\end{array}$ & & $\begin{array}{r}1728 \\
-1132.78\end{array}$ & & $\begin{array}{r}1728 \\
-1130.56\end{array}$ \\
\hline
\end{tabular}

Note: Numbers in bold are statistically significant at the $5 \%$ level.

In model 1 , we observe that the average transition rate into the state Out is $22 \%$ higher for 
individuals receiving starthelp, but it is not statistically significant at a $5 \%$ level. Regarding the explanatory variables, we find that persons aged 30-49 have much lower exit rates to this state than the young and older workers. It is perhaps somewhat surprising that the young workers have high transition rates into this state that can best be characterized as 'outside the labour market', but since education is included in the Employment state, we cannot interpret the results in any other way. Married individuals have higher transition rates into the state Out, but if their partner receives starthelp or social assistance, this pattern is reversed. Persons from Afghanistan have significantly higher transition rates into Out than the remainder of the refugee immigrants. The higher the schooling level the higher the transition rate, but the differences between the levels are not statistically significant. This is a bit surprising to us since we would have expected those with higher schooling levels to stay longer in the labour force than those with lower schooling levels. However, since we cannot exclude the possibility that 'Out' also consists of emigrants who just have not told the authorities that they have emigrated, there is a plausible eplanation for this finding, although it cannot be tested due to lack of data. Finally, refugees initially located in Copenhagen have a higher transition rate into Out.

In model 2 we allow for a more flexible baseline. The baseline seems to fluctuate around some level but without any kind of trend. In model 3 we have restricted the baseline to three intervals and the treatment effect is divided into two intervals based on the general-to-speific strategy. It is seen that there is a positive treatment effect for the first twelve months, but after the first twelve months the treatment effect is close to zero.

\section{Results with calendar time effects}

The motivation for thinking that calendar time effects may be important is best explained with a look at Figure 3. Figure 3 displays exit rates from 'temporary public income transfers' to Employment, but they are organized by calendar time rather than duration. That is, the transition rate from public income transfers to Employment in month 12 is the number of individuals finding employment in December 2002 divided by the population at risk, i.e. those who received public income transfers in November 2002.

The graph strongly suggests that there is a calendar time effect in the sense that the exit rate into employment is high in 2003 and even higher in 2004, and especially so in January 2003 and 2004. This could be due to an undiscovered problem in the data, but there were no more obvious flaws in the raw data, so we shall control for this by including dummies for these calendar time months in the regressions. It could also just be that there are a lot of job openings in January. The point is that this pattern is there for the treatment as well as the control group, hence, it is not likely to be a treatment effect. If it were, then we would expect a gradual increase in the hazard for the treatment group and not a jump simultaneous to that of the control group.

It could therefore be important to control for this calendar time effect. Neglecting to do so would lead to upward biased estimates of the effect of starthelp; individuals in the treatment 


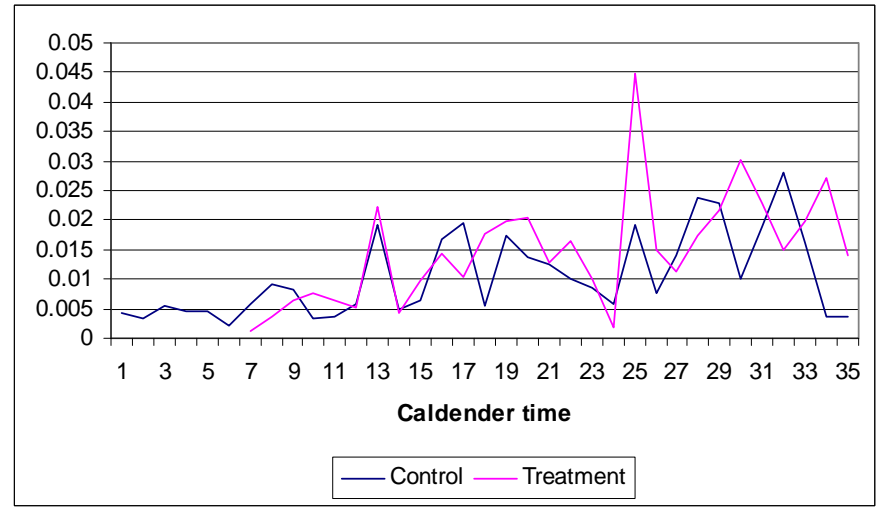

Figure 3: Transition rates into job by calendar time

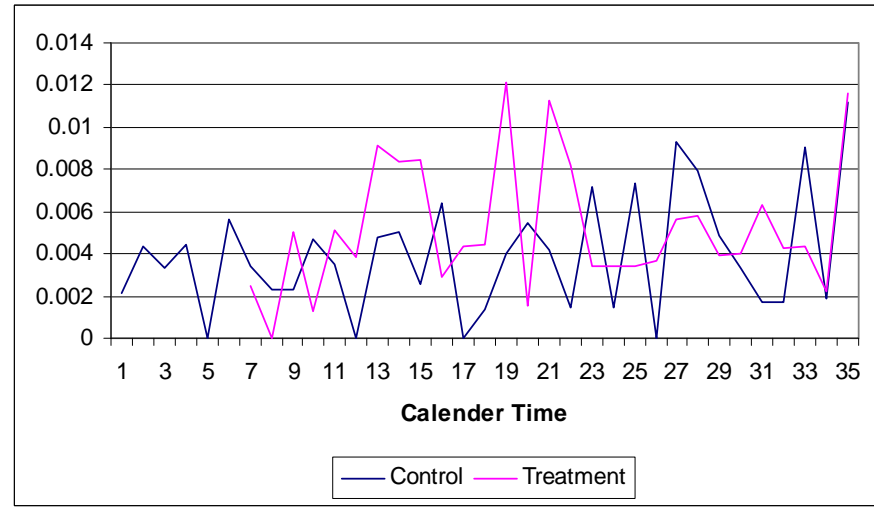

Figure 4: Transition rates into Out by calendar time

group receive their residence permit and thus commence their spells of public income transfer in the second half-year of 2002, so they will on average be 'hit' by the 'January 2003' calendar time effect at an earlier stage in their duration process than the controls, and it will therefore materialize as an upward biased treatment effect unless accounted for. Figure 4 shows the similar data transformation for transitions into the state Out.

The evidence for calendar time effects is not nearly as obvious here as in the case of transitions into Employment. We therefore expect this to turn up in the estimation such that our results are not significantly changed.

We now turn to Table 4, which contains models for the transitions into Employment. It turns out that the treatment effect is sensitive to the specification of the calendar time effects as we would expect, given the graphs above. We have therefore chosen to estimate the model going from general-to-specific. The estimation process has been the following: First, the estimation of the fully flexible model, i.e. completely flexible baseline, treatment and calender time effects. Second, LR-test statistics are used to test the model down. We arrive at the model specification presented in Table 4, Model 5. Model 4 is arrived at in a similar way, but with a time-invariant treatment effect. The estimates of the covariates do not change very much compared to the results in table 
2 so they are not reported here, but they are available from the authors on request.

Table 4: Estimation results for transition into Employment, calendar time effects included

\begin{tabular}{|c|c|c|c|c|}
\hline & \multicolumn{2}{|l|}{ Model 4} & \multicolumn{2}{|l|}{ Model 5} \\
\hline & Est. & Std. Err. & Est. & Std. Err \\
\hline \multicolumn{5}{|l|}{ Treatment effects } \\
\hline ATE & 0.367 & 0.137 & & \\
\hline ATE Month 1-5 & & & -0.094 & 0.358 \\
\hline ATE Month 6-12 & & & 0.808 & 0.243 \\
\hline ATE Month 13-24 & & & 0.156 & 0.172 \\
\hline ATE Month 25+ & & & 1.015 & 0.315 \\
\hline \multicolumn{5}{|l|}{ Baseline } \\
\hline Month 1 & -1.757 & 0.631 & -1.757 & 0.631 \\
\hline Month 2 & -3.363 & 0.752 & -3.363 & 0.752 \\
\hline Month 3-4 & -2.775 & 0.704 & -2.775 & 0.704 \\
\hline Month 5-8 & -2.943 & 0.703 & -2.943 & 0.703 \\
\hline Month 9 & -2.666 & 0.741 & -2.666 & 0.741 \\
\hline Month 10-11 & -2.798 & 0.736 & -2.798 & 0.736 \\
\hline Month 12-13 & -2.559 & 0.738 & -2.559 & 0.738 \\
\hline Month 14 & -2.137 & 0.762 & -2.137 & 0.762 \\
\hline Month 15-18 & -2.651 & 0.753 & -2.651 & 0.753 \\
\hline Month 19-21 & -2.513 & 0.776 & -2.513 & 0.776 \\
\hline Month 22 & -2.818 & 0.819 & -2.818 & 0.819 \\
\hline Month 23-24 & -2.320 & 0.791 & -2.320 & 0.791 \\
\hline Month 25 & -2.849 & 0.850 & -2.849 & 0.850 \\
\hline Month 26-29 & -2.182 & 0.832 & -2.182 & 0.832 \\
\hline Month 30-32 & -2.758 & 0.893 & -2.758 & 0.893 \\
\hline Month 35+ & -2.263 & 0.975 & -2.263 & 0.975 \\
\hline \multicolumn{5}{|l|}{ Calender time } \\
\hline \multicolumn{5}{|l|}{ Jan. 2002 (base) } \\
\hline Feb. 2002 - May 2002 & -0.509 & 0.574 & -0.469 & 0.574 \\
\hline June 2002 & -1.517 & 0.884 & -1.385 & 0.889 \\
\hline July 2002 & -0.393 & 0.667 & -0.073 & 0.711 \\
\hline Aug. 2002 - Sept. 2002 & 0.136 & 0.576 & 0.548 & 0.634 \\
\hline Nov. 2002 - Feb. 2003 & -0.626 & 0.566 & -0.151 & 0.667 \\
\hline Mar. 2003 - Mar. 2004 & 0.406 & 0.626 & 0.598 & 0.745 \\
\hline Apr. 2004 - Aug. 2004 & 0.864 & 0.691 & 1.213 & 0.787 \\
\hline Sept. 2004 & 0.753 & 0.750 & 0.966 & 0.835 \\
\hline Oct. 2004 & 0.479 & 0.769 & 0.608 & 0.852 \\
\hline Nov. 2004 & -0.050 & 0.816 & -0.041 & 0.885 \\
\hline Jan. 2003 & 1.612 & 0.266 & 1.603 & 0.271 \\
\hline Jan. 2004 & 0.825 & 0.194 & 0.900 & 0.198 \\
\hline Dec. 2003 & -1.311 & 0.459 & -1.229 & 0.463 \\
\hline \multicolumn{5}{|l|}{ Covariates } \\
\hline Included & Yes & & Yes & \\
\hline $\begin{array}{l}\text { Number of obs. } \\
\text { LogLikelihood }\end{array}$ & & $\begin{array}{r}1728 \\
-2439.01\end{array}$ & & $\begin{array}{r}1728 \\
-2432.35\end{array}$ \\
\hline
\end{tabular}

Note: Numbers in bold are statistically significant at the $5 \%$ level. 
In models 4 and 5, we see that the inclusion of calendar time has the implication that the treatment effect has changed, which was also what we would expect given the graphical inspection of figure 3. The calendar time effect is roughly increasing until spring 2003 where it settles at a fairly constant level until October and November 2004, where there is a drop. We also see that the three monthly dummies for December 2003, January 2003 and January 2004 are statistically significant. The baseline increases a little over time, but not as much as in model 2 and 3. The positive and significant ATE in model 4 is comprised of somewhat different monthly treatment effects. The ATE is significantly positive for months $6-12$ and then again after 2 years, but in months 1-5 and 13-24, it is not significantly different from zero. This is very different results when compared to model 3, where the treatment effect was highest just after receipt of the permanent recidence permit. A cautious interpretation could be that when the immigrants first arrive in Denmark, they have so few qualifications of use in the Danish labour market that they receive no job offers - they are, in a sense, temporarily unemployable. As they follow the Introduction Program they gradually accumulate skills and knowledge essential to conducting search and receiving job offers. When this happens, the lower reservation wage for those on 'starthelp' shows some importance. This interpretation is consistent with the increase in the ATE at 25 months onwards, but the positive effects in months $6-12$ is difficult to explain with this line of argumentation. There could be some fast learners - those with the best skills - who learn the language fast and adapt quickly, but we shall return to this issue when discussing heterogenous treatment effects. However, it is important to notice that these effects act multiplicatively on the hazard rate, and since both the baseline and calendar time effects are increasing over time, the implication is that the absolute size of the effect is much larger after two years than in the 6-12 month interval.

Table 5 contains similar estimates for the transition into the state Out 
Table 5: Estimation results for transition into Out, calendar time effects included

\begin{tabular}{|c|c|c|c|c|}
\hline & \multicolumn{2}{|l|}{ Model 4} & \multicolumn{2}{|l|}{ |Model 5} \\
\hline & Est. & Std. Err. & Est. & Std. Err \\
\hline $\begin{array}{l}\text { Treatment effects } \\
\text { ATF }\end{array}$ & 0.438 & 0196 & & \\
\hline ATE Month 1-12 & & & & 0.246 \\
\hline $\begin{array}{l}\text { ATE Month 13+ } \\
\text { Baseline }\end{array}$ & & & 0.215 & 0.285 \\
\hline Month 1-11 & -4.646 & 0.898 & -4.649 & 0.899 \\
\hline Month 12-17 & -4.802 & 0.957 & -4.649 & 0.965 \\
\hline Month 18-22 & -4.271 & 0.969 & -4.109 & 0.989 \\
\hline Month 23-28 & -4.377 & 1.025 & -4.326 & 1.033 \\
\hline Month 29-33 & -3.484 & 1.076 & -3.564 & 1.079 \\
\hline Month 34+ & -2.714 & 1.225 & -2.805 & 1.227 \\
\hline $\begin{array}{l}\text { Calender time } \\
\text { Jan. } 2002 \text { (base) }\end{array}$ & & & & \\
\hline Feb. 2002 - July 2002 & -0.799 & 0.747 & -0.806 & 0.747 \\
\hline Aug. 2002 - Apr. 2003 & -1.111 & 0.749 & -1.211 & 0.756 \\
\hline May 2003 - Feb. 2004 & -1.224 & 0.794 & -1.349 & 0.803 \\
\hline Mar. 2004 - May 2004 & -1.088 & 0.868 & -1.073 & 0.872 \\
\hline June 2004 - & -1.725 & 0.892 & -1.637 & 0.893 \\
\hline $\begin{array}{l}\text { Covariates } \\
\text { Included }\end{array}$ & Yes & & Yes & \\
\hline $\begin{array}{l}\text { Number of obs. } \\
\text { LogLikelihood }\end{array}$ & & $\begin{array}{r}1728 \\
-1129.18\end{array}$ & & $\begin{array}{r}1728 \\
-1128.61\end{array}$ \\
\hline
\end{tabular}

Note: Numbers in bold are statistically significant at the $5 \%$

level.

The results from this specification with calendar time effects are essentially the same as the results without calendar time effects. This was also what we would expect given figure 4 above. The ATE is still only significant in the beginning of the time in Denmark. This could be interpreted as if those who want to leave the labour force because of the lower transfer payment do it quite early in their stay in Denmark.

It still remains to discuss the nature of this calendar time effect. It may consist of a number of components. First of all, although there was a minor setback in the cyclical conditions during this period, the economy was in a fine shape, and labour demand was still quite high. Hence, there may be a general trend towards better conditions in the labour market for immigrants, including refugee immigrants. Secondly, part of the calendar time effect may be due to unresolved data issues, that is, there may still be some problems with the data, as exemplified by the high transition rate into Employment in January 2003. Thirdly, there may have been other reforms or changes in administrative rules that we are unaware of that were implemented during the observation period. However, as yet, we have been unable to find the explanation behind this peculiar calendar time 
effect. Our best guess is that two more things play important roles; first, there was a large drop in the inflow of immigrants (refugees and others) starting in 2002. As the administrative burden on case workers are gradualy eased, this may lead to more and better help in finding employment. Moreover, the gradual intensification in integration policies that have taken place since 1999, where the Introduction Program was introduced, have probably also played a role in improving the Employment prospects for refugee immigrants.

Nevertheless, our primary interest is the treatment effect and not the reasons for the calendar time effect, so our preliminary conclusion is that there is little effect on the job finding rate in the first two years, thereafter there is a large increase. There is a significant positive effect on the rate at which immigrant refugees leave the labour force, but this is only in the first twelve months, thereafter this effect is zero.

In Appendix $\mathrm{A}$ we show the results from more flexible models for both the hazard rate into Employment and Out. They do not alter our results.

\section{Heterogeneous treatment effects}

So far we have estimated an ATE, but it is likely that there are heterogenous treatment effects, i.e. that different groups are affected differently by the reform. One might imagine that refugees with a higher level of schooling and therefore perhaps better opportunities in the labour market have a larger treatment effect. It is also possible that the effect differs across gender, age, ethnicity etc.

To check for heterogenous treatment effects we start from model $5,{ }^{13}$ and we include dummies which are products of characteristics and treatment status. The duration model is non-linear and so the coefficient estimate of the interaction dummy in the regression does not represent the marginal effect in which we are interested, cf. Ai \& Norton (2003). This is seen from the calculations below, where calendar time effects are ignored for expositional convenience. Let $x_{t}$ denote the set of $x$ 's for which we are interested in an interaction effect, and denote by $z_{t}$ the remaining $x$ 's.

$$
\begin{array}{r}
\theta_{i}\left(t \mid z_{t}, x_{t}, d\right)=\lambda_{i}(t) \cdot \exp \left(z_{t} \alpha_{i}+x_{t} \beta_{i}+d \gamma_{i t}+x_{t} \cdot d \cdot \delta_{i t}\right) \\
\frac{\Delta \theta\left(t \mid z_{t}, x_{t}, d\right)}{\Delta d}=\lambda_{i}(t) \cdot \exp \left(z_{t} \alpha_{i}+x_{t} \beta_{i}\right) \cdot\left(\exp \left(\gamma_{i t}+x_{t} \delta_{i t}\right)-1\right)
\end{array}
$$

However, this marginal effect contains the $x$ 's and $z$ 's and therefore ideally it has to be computed for each individual, and there is a comlex issue with respect to the duration times at which they should be measured, so we choose the following strategy: Conditioning on a value of $x$ and $z$, we obtain the marginal treatment effect for individuals with characteristics $x$ and $z$, and dividing

\footnotetext{
${ }^{13}$ We have also tried with a fully flexible model but this makes no significant difference.
} 
through with the hazard rate in the non-treatment state, we obtain the relative effect

$$
\frac{\frac{\Delta \theta\left(t \mid z_{t}, x_{t}, d\right)}{\Delta d}}{\theta_{i}\left(t \mid z_{t}, x_{t}, d=0\right)}=\exp \left(\gamma_{i t}+x_{t} \delta_{i t}\right)-1
$$

The relative effect, however, is not very informative if we are interested in the absolute effect, so therefore we report also the relative hazard rate for the $x$ that treatment is interacted with, that is, we report $\exp \left(\beta_{i}\right)-1$. We use equation (3) above to transform the effects and calculate the std. err. by the delta method. Table 6 contains the results from this estimation from model 4 (the constant treatment effect model) ${ }^{14}$.

Table 6: Estimation results for more flexible models of the hazard into Job

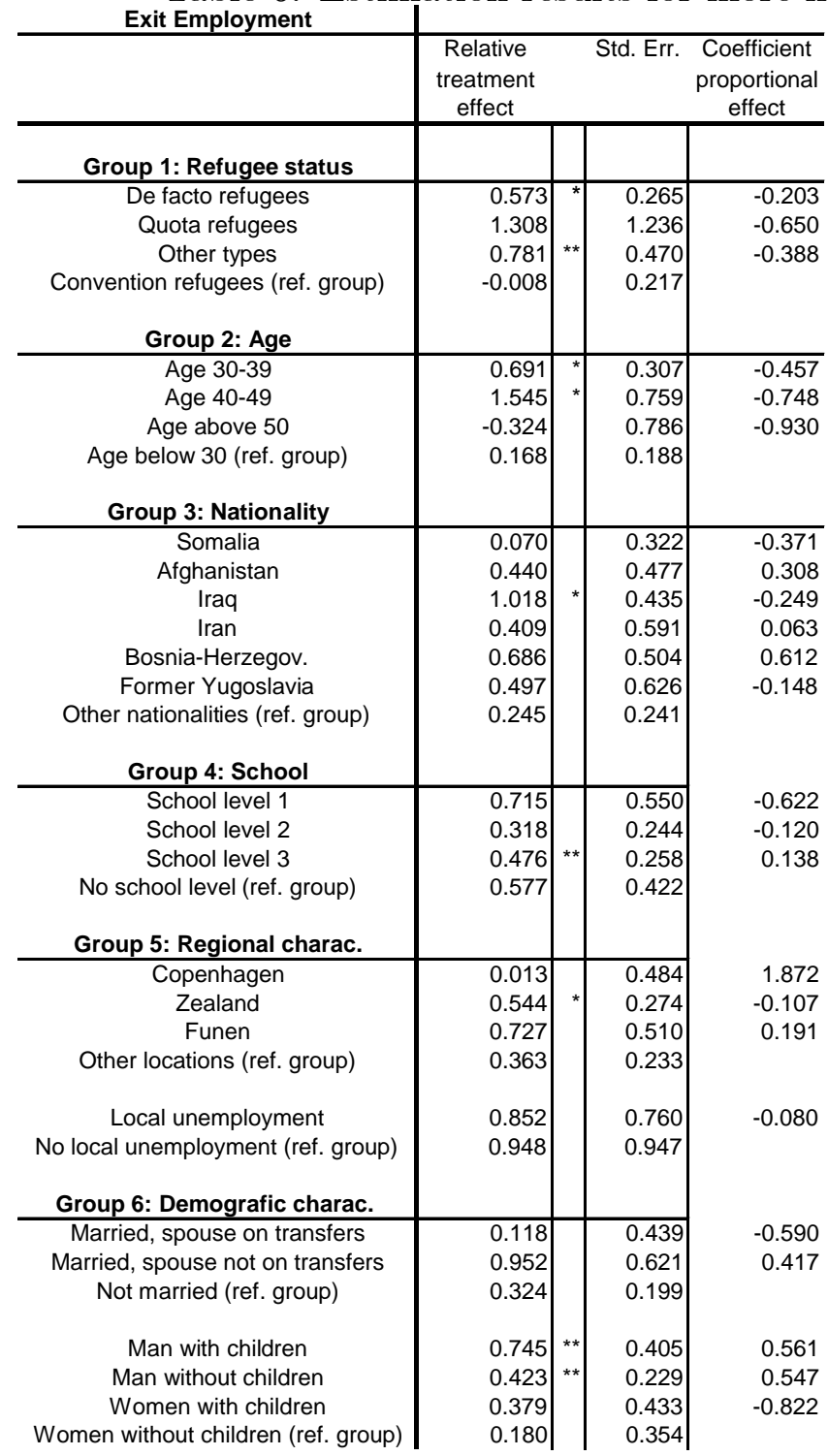

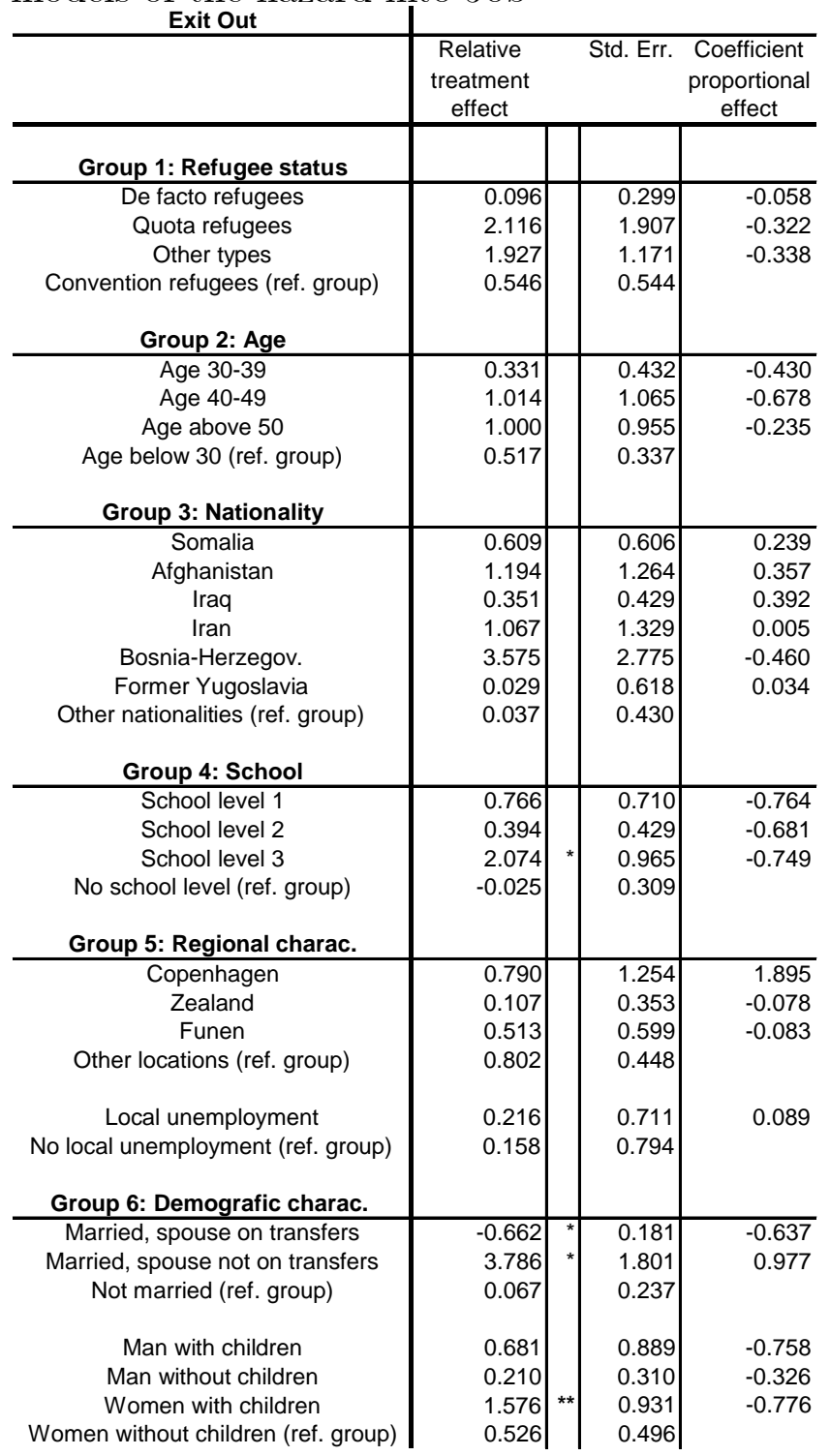

Note: ${ }^{* *}$ denotes significance at the $10 \%$ level, while ${ }^{*}$ denotes significance at the $5 \%$ level.

From table 6 it is apparent that the treatment effect is not constant across individuals. If

\footnotetext{
${ }^{14}$ We have estimated the different interacton effects groupwise in separate models.
} 
we look at the exit rate to Employment there is a larger treatment effect for all other types of refugees than convention refugees, which is the reference group. Although de facto and other refugee categories have a lower transition rate into Employment, this heterogeneous treatment effect is non-negligible.

Although those aged 30-50 have lower transition rates into Employment in general, they have larger treatment effects, also in absolute terms, than the younger group.

There is also a larger effect of receiving starthelp if the refugee is from Iraq as compared to all other origin countries.

If the multiplicative treatment effect for schooling levels is normalised with the size of the transition rate into Employment, more education (as approximated by the language school starting level) uniformly increases the treatment effect; this implies that the higher the skill level the more responsiveness to economic incentives. The tratment effect is only statistically significant for those with the highest educational levels.

Looking at regional aspects, the treatment effect is only statistically significant on Zealand.

Married persons have a large treatment effect, although it is not significant statistically. However, if the spouse is on public income transfers this reduces the treatment effect dramatically.

There is generally a smaller treatment effect for women than for men, especially when it is noted that women have a lower transition rate into Employment than men. Moreover, only men have statistically significant treatment effects. The treatment effect is largest for men with children, and it is essentially zero in absolute terms for women with children and very low for women without children.

When we turn to the transition rate to Out - non-participation - we see that not many of the estimated heterogneous effects are statistically significant. There is a statistically significant higher treatment effect to Out for refugees with the highest educational level. This is unexpected, since refugees with high educational have a higher exit rate into Employment and are also more responsive to the treatment with respect to transitions into Employment. A possible explanation behind this pattern could be unreported emigration (which we cannot detected in the data), or alternatively it could be that well educated refugees have good alternatives to starthelp AND employment. We can only speculate, as the data is not informative about this.

Refugees that are married but whose spouse is not on public transfers has a very high exit rate into Out when the comparison group is those not married. This is probably not a behavioural response but rather a consequence of the fact that when one person in the couple finds employment, the other loses the right to public income transfers at a lower monthly wage for those receiving starhelp than for those receiving the higer income transfer. Married individuals whose spouses are on public income transfers have a significantly negative treatment effect, the interpretation being that there are no incentives to leave the labour force when both spouses receive starthelp. Women with children have a significant treatment effect on the transition rate into Out.

The reason that - in table 6 - we have used the model with a time-invariant treatment effect is that if we have time varying treatment effects this results in different interaction effects for each 
different treatment effect and then the general pattern is difficult to assess. However, since we have found that the treatment effect is time dependent, we have calculated these different interaction effects and we will now discuss a selection of the results (See Appendix B for complete results on all variables and std. err.). The results show that the heterogeneous treatment effects generally follows the same pattern as the homogenous time-varying treatment effects reported in table 4 .

For the schooling level variable, for example, the treatment effect is only statistically significant after two years for those with the lowest educational levels, and keeping in mind the low transition rate into employment that the treatment effect affects, the implication is that this group is virtually immune to the treatment. This suggests an interpretation that it is the increasing level of human capital, which after two years in Denmark has increased so much that - at least for some groups there are better employment opportunities. Other interaction effects have time-varying patterns, and the results can be inspected in Appendix B.

\section{Unobserved heterogeneity}

We have made the functional form assumption that the exit rates have a MPH form. This can be used to try to identify if there is any unobserved heterogeneity uncorrelated with the observed variables. The identification argument is given above in section 4.2. If left unaccounted for, unobserved heterogeneity will bias the duration dependence towards more negative values. This is because the group of survivors at any given time $t_{1}>0$ will have less favorable unobserved characteristics in terms of the probability of exit than the initial group and than the group of survivors at $t_{2}<t_{1}$. Neglecting the unobserved heterogeneity will also bias the coefficients of the explanatory variables, see Lancaster (1990).

First we estimate the model where we assume that there is no correlation between the unobserved components in the two exit rates. We are using the approach from Heckman \& Singer (1984) specifying the mixture distribution as a discrete distribution starting with two mass points and expanding the number of mass points until we reach the point where the extra mass point is has a probability of zero. Table 7 summarizes the results for two mass points 
Table 7: Estimation results seperate states with the mixture distribution specified as two mass points

\begin{tabular}{|c|c|c|c|c|c|}
\hline Hazard to employment & & & Hazard to Out & & \\
\hline & Est. & Std. Err. & & Est. & Std. Err. \\
\hline$\overline{\text { Treatment effects }}$ & & & $\overline{\text { Treatment effects }}$ & & \\
\hline ATE Month $1-5$ & -0.118 & 0.168 & ATE Month 1-12 & 0.452 & 0.291 \\
\hline ATE Month 6-12 & 0.793 & 0.077 & ATE Month $13+$ & 0.165 & 0.369 \\
\hline ATE Month 13-24 & 0.155 & 0.040 & & & \\
\hline ATE Month $25+$ & 1.006 & 0.157 & & & \\
\hline Baseline & & & Baseline & & \\
\hline Month 1 & -1.852 & $1.30 \mathrm{E}+05$ & Month 1-11 & -4.224 & 1.073 \\
\hline Month 2 & -3.643 & $1.30 \mathrm{E}+05$ & Month 12-17 & -4.194 & 1.120 \\
\hline Month 3-4 & -2.981 & $1.30 \mathrm{E}+05$ & Month $18-22$ & -3.672 & 1.172 \\
\hline Month 5-8 & -3.566 & $1.30 \mathrm{E}+05$ & Month 23-28 & -3.846 & 1.244 \\
\hline Month 9 & -3.378 & $1.30 \mathrm{E}+05$ & Month 29-33 & -3.076 & 1.408 \\
\hline Month 10-11 & -3.476 & $1.30 \mathrm{E}+05$ & Month 34+ & -2.208 & 1.490 \\
\hline Month 12-13 & -3.065 & $1.30 \mathrm{E}+05$ & & & \\
\hline Month 14 & -2.414 & $1.30 \mathrm{E}+05$ & & & \\
\hline Month 15-18 & -2.922 & $1.30 \mathrm{E}+05$ & & & \\
\hline Month 19-21 & -2.827 & $1.30 \mathrm{E}+05$ & & & \\
\hline Month 22 & -3.127 & $1.30 \mathrm{E}+05$ & & & \\
\hline Month 23-24 & -2.641 & $1.30 \mathrm{E}+05$ & & & \\
\hline Month 25 & -3.511 & $1.30 \mathrm{E}+05$ & & & \\
\hline Month 26-29 & -2.744 & $1.30 \mathrm{E}+05$ & & & \\
\hline Month 30-32 & -3.161 & $1.30 \mathrm{E}+05$ & & & \\
\hline Month $35+$ & -2.524 & $1.30 \mathrm{E}+05$ & & & \\
\hline Calender time & & & Calender time & & \\
\hline Jan. 2002 (base) & & & Jan. 2002 (base) & & \\
\hline Feb. 2002 - May 2002 & -0.408 & 0.368 & Feb. 2002 - July 2002 & -0.800 & 0.820 \\
\hline June 2002 & -1.312 & 0.854 & Aug. 2002 - Apr. 2003 & -1.121 & 0.823 \\
\hline July 2002 & 0.003 & 0.572 & May 2003 - Feb. 2004 & -1.229 & 0.869 \\
\hline Aug. 2002 - Sept. 2002 & 0.621 & 0.497 & Mar. 2004 - May 2004 & -0.963 & 0.976 \\
\hline Nov. 2002 - Feb. 2003 & -0.066 & 0.561 & June 2004 - & -1.524 & 1.085 \\
\hline Mar. 2003 - Mar. 2004 & 0.693 & 0.652 & & & \\
\hline Apr. 2004 - Aug. 2004 & 1.296 & 0.721 & & & \\
\hline Sept. 2004 & 1.057 & 0.821 & & & \\
\hline Oct. 2004 & 0.700 & 0.861 & & & \\
\hline Nov. 2004 & 0.052 & 0.961 & & & \\
\hline Jan. 2003 & 1.606 & 0.076 & & & \\
\hline Dec. 2003 & -1.217 & 0.225 & & & \\
\hline Jan. 2004 & 0.883 & 0.047 & & & \\
\hline Covariates & & & Covariates & & \\
\hline Included & Yes & & Included & Yes & \\
\hline Unobserved het. & & & Unobserved het. & & \\
\hline $\mathrm{v}_{\mathrm{j}}^{\mathrm{a}}$ & 0.048 & $9.98 \mathrm{E}+04$ & $v_{0}{ }^{a}$ & -12.151 & \\
\hline$P\left(v_{j}=v_{j}{ }^{a}\right)$ & 0.690 & $1.85 \mathrm{E}+09$ & $P\left(v_{0}=v_{0}^{a}\right)$ & 0.377 & 0.127 \\
\hline$P\left(v_{j}=v_{j}^{b}=0\right)$ & 0.310 & $1.85 \mathrm{E}+09$ & $P\left(v_{0}=v_{0}^{b}=0\right)$ & 0.623 & 0.127 \\
\hline Number of obs. & & 1728 & Number of obs. & & $\overline{1728}$ \\
\hline
\end{tabular}

In table 7 it is seen that we cannot identify any unobserved heterogeneity in the Employment hazard. There could be several explanations for this. We have relatively few observations and 
many parameters, and we only have single-spell data, so perhaps there is not enough actual variation to identify the mixture parameters. Another problem could be that we do not have continuous explanatory variables which the identification argument relies on, cf. section 4.2. The last possibility is that there is no unobserved heterogeneity, this seems unlikely since it would imply that we have taken into account all variables that are determining the exit process into Employment.

If we turn to the hazard into Out we see, that we are able to identify two different types. The first type with $v_{o}=v_{o}^{a}$ has a zero exit rate into Out ${ }^{15}$. This group consists of $37.7 \%$ of the refugee immigrats. We have have tried increasing the number of mass point for both exit states to three but this estimation degenerated into the findings in table 7 above. Since we have not been able to identify different types in the hazard into employment there is no reason to specify a full model.

\section{Robustness}

The results presented so far have been based on the hypothesis of a quasi-natural experiment, that is, there is no systematic selection with respect to unobserved characteristics between those arriving in the first half of 2002 and the second half of 2002. Could there be different institutional settings applying to the two groups of refugee immigrants arriving in the first half-year and in the second? Could there is some kind of systematic selection, for example, that the most able (or most needy) are selected first? ${ }^{16}$ To make the assumption more trustworthy we have used the same setup to analyze the effect of arriving in the first half-year compared to the second half-year in different years than 2002. ${ }^{17}$ If our assumption is correct we would not expect to find any significant differences between the two groups in terms of the hazards. Table 8 contains the results from the model where the calender time and baseline is flexible but there is assumed a constant effect of arriving in the second half-year compared to the first. If this effect is present then it might also be present in 2002 where we wrongfully interpret it as a treatment effect of lower benefits. The model is estimated both for the full time period up to 2004 and for a three year time period which is the length that we have data for in the cohort from 2002.

\footnotetext{
${ }^{15}$ The reason there is no std. err. on $v_{o}^{a}$ is that the likelihood function is almost flat in this region since, so the std. err. are huge. To correct this we fix $v_{o}^{a}$ and calculate the std. err. of all the other parameters.

${ }^{16}$ Phone interviews with caseworkers at The Danish Immigration Service suggest that there is no deliberate selection.

${ }^{17}$ Because of more serious problems in registering the first month on social assistance in the data, we have used a 5 months initial correction window instead of only 3 months.
} 
Table 8: Estimation results for constant treatment effect 1999-2001 and 2003

\begin{tabular}{|c|c|c|c|c|c|}
\hline \multicolumn{3}{|l|}{ Exit to job } & \multicolumn{3}{|l|}{ Exit to Out } \\
\hline 1999 & & & 1999 & & \\
\hline Full time period & $\begin{array}{l}\text { Coefficient } \\
\text { Std. Err }\end{array}$ & $\begin{array}{l}0.095 \\
0.167\end{array}$ & Full time period & $\begin{array}{l}\text { Coefficient } \\
\text { Std. Err }\end{array}$ & $\begin{array}{l}0.030 \\
0.241\end{array}$ \\
\hline 3 years time period & $\begin{array}{l}\text { Coefficient } \\
\text { Std. Err }\end{array}$ & $\begin{array}{l}0.228 \\
0.237\end{array}$ & 3 years time period & $\begin{array}{l}\text { Coefficient } \\
\text { Std. Err }\end{array}$ & $\begin{array}{l}0.430 \\
0.430\end{array}$ \\
\hline 2000 & & & 2000 & & \\
\hline Full time period & $\begin{array}{l}\text { Coefficient } \\
\text { Std. Err }\end{array}$ & $\begin{array}{l}0.125 \\
0.138\end{array}$ & Full time period & $\begin{array}{l}\text { Coefficient } \\
\text { Std. Err }\end{array}$ & $\begin{array}{r}-0.055 \\
0.259\end{array}$ \\
\hline 3 years time period & $\begin{array}{l}\text { Coefficient } \\
\text { Std. Err }\end{array}$ & $\begin{array}{r}-0.044 \\
0.188\end{array}$ & 3 years time period & $\begin{array}{l}\text { Coefficient } \\
\text { Std. Err }\end{array}$ & $\begin{array}{r}-0.324 \\
0.384\end{array}$ \\
\hline 2001 & & & 2001 & & \\
\hline Full time period & $\begin{array}{l}\text { Coefficient } \\
\text { Std. Err }\end{array}$ & $\begin{array}{r}-0.302 \\
0.124\end{array}$ & Full time period & $\begin{array}{l}\text { Coefficient } \\
\text { Std. Err }\end{array}$ & $\begin{array}{l}0.306 \\
0.231\end{array}$ \\
\hline 3 years time period & $\begin{array}{l}\text { Coefficient } \\
\text { Std. Err }\end{array}$ & $\begin{array}{r}-0.505 \\
0.148\end{array}$ & 3 years time period & $\begin{array}{l}\text { Coefficient } \\
\text { Std. Err }\end{array}$ & $\begin{array}{l}0.371 \\
0.300\end{array}$ \\
\hline 2003 & & & 2003 & & \\
\hline Full time period & $\begin{array}{l}\text { Coefficient } \\
\text { Std. Err }\end{array}$ & $\begin{array}{r}-0.045 \\
0.317\end{array}$ & Full time period & $\begin{array}{l}\text { Coefficient } \\
\text { Std. Err }\end{array}$ & $\begin{array}{l}0.207 \\
0.601\end{array}$ \\
\hline
\end{tabular}

Note: Numbers in bold are statistically significant at the $5 \%$ level.

Looking at table 8, we see that in 2001 the effect of arriving in the second half-year on exit to employment is negative and significant. Besides this there is no significant effect in any of the years on either the hazard into Employment or into Out. Careful inspections of the data suggest that the cohort arriving in the first half of 2001 is different from the other cohorts in a number of respects, so having in mind that there is a problem with those arriving in the first half of 2001, we do believe that the experiment is reasonably valid in the sense that there are no unobserved differences between the groups arriving in the first and second half of a year. ${ }^{18}$

As we have shown above the results, especially regarding transitions into Employment, change with the inclusion of the calendar time effect. Therefore the basis for this inclusion has to be investigated further. The argument could be made that the effect we have labelled a calendar-time effect is really only some kind of assimilation process due to the treatment. One way to make a kind of robustness check is to see if the calender time effect is the same for different populations. We have chosen to look at the cohorts arriving in 2001 and 2003. The reason for the choice of 2001 and 2003 is the following. Since the calender time effect is affecting individuals in the same way, the underlying assumption, if we were to compare the cohorts from 2000 and 2002, would be that the effect is the same for individuals who have just come to the country and individuals who have been here for 2 years. We estimate the hazard for exit to Employment with fully flexible baseline, treatment and calender time effects. The result for the calender time estimates can be

\footnotetext{
${ }^{18}$ We have tried to estimate the model based on the population medio 2001 - medio 2003, i.e. such that there is a year on both sides of the rule change. This does not alter our results. We have also tried to validate this by comparing the cohort arriving in medio 1999-medio 2000 to the cohort arriving in medio 2000-medio 2001. There is no significant differences between the two.
} 


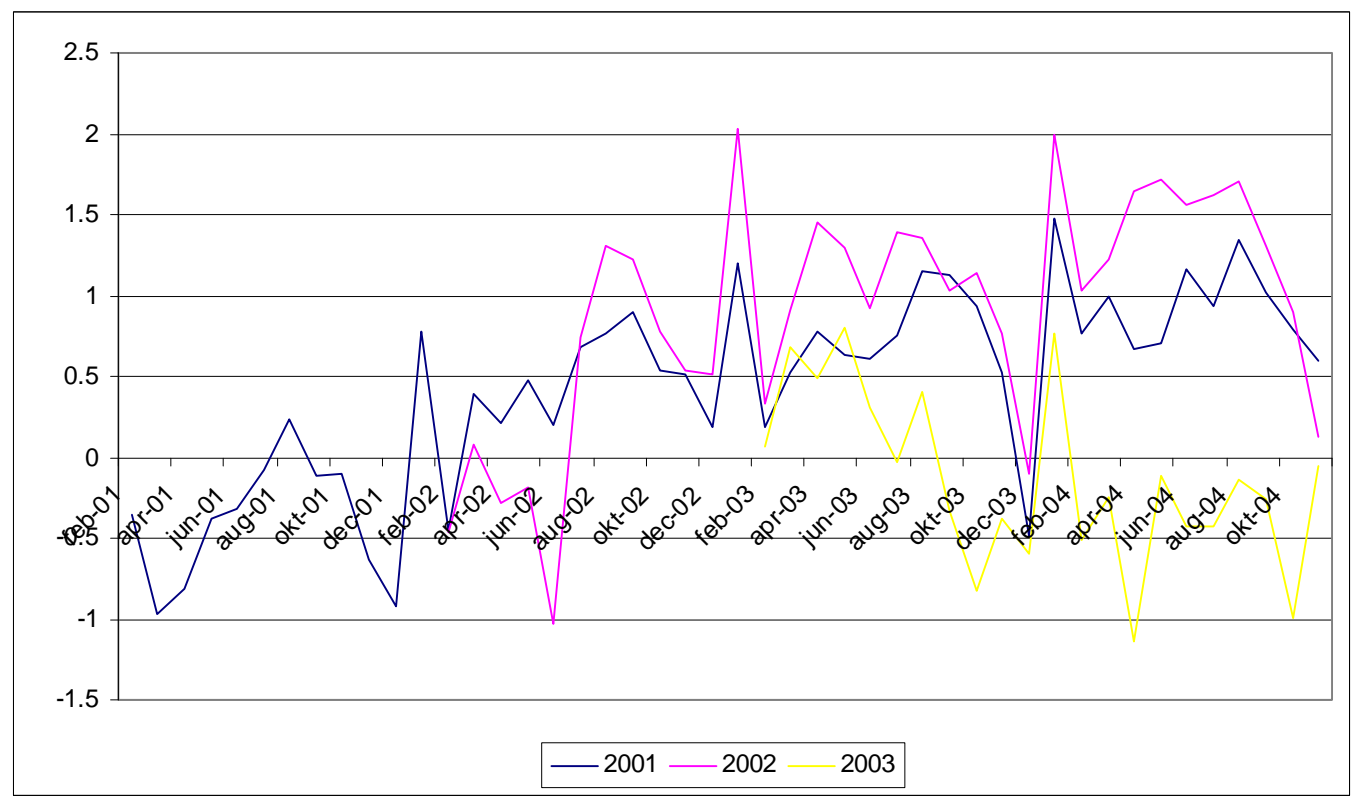

Figure 5: Calender time effects for cohorts arriving in 2001, 2002 and 2003 for the hazard into Employment

seen in figure 5 .

We see that the calender time estimates from the cohort arriving in 2001 have the same shape as those from the cohort from 2002. Remember that these effects have different bases, i.e. the effect for February 2001 is relative to the effect in January 2001 etc., so the only thing that we can compare is the shape. The shape of the estimates from the cohort of 2003 also almost fits. It is almost flat, which is also the case for the period 2003-2004 for the cohorts from 2001 \& 2002 . This is suggestive evidence that our calender time effect is fairly robust, but there is a risk that our results are biased, but it is difficult to see a way out of this problem.

Since we have chosen a MPH framework one might suspect that some of the results are driving by the functional form of this model. To test this we have estimate the duraation model with a random effects (RE) sequence of probits and a RE sequence of linear probability models (OLS). The RE OLS has a linear functional form. This implies that unobserved heterogeneity that is uncorrelated with the explanatory variables does not bias the estimated parameters. The results for the treatment effect can be seen in figure 6 , while the results for the calender time effects and baselines can be seen in Appendix C.

As can be seen from figure 6 , the basic structure of the treatment effect is roughly the same no matter what functional form specification we use. This is reassuring, because it is suggestive evidence that it is not the functional form which is driving the results, and that our inability to identify any unobserved heterogeneity in the hazard rate into Employment does not alter the conclusion qualitatively.

Since the control and treatment group are different in terms of observed characteristics one might be concerned that the thing driving the results could be a wrong functional form assumption 

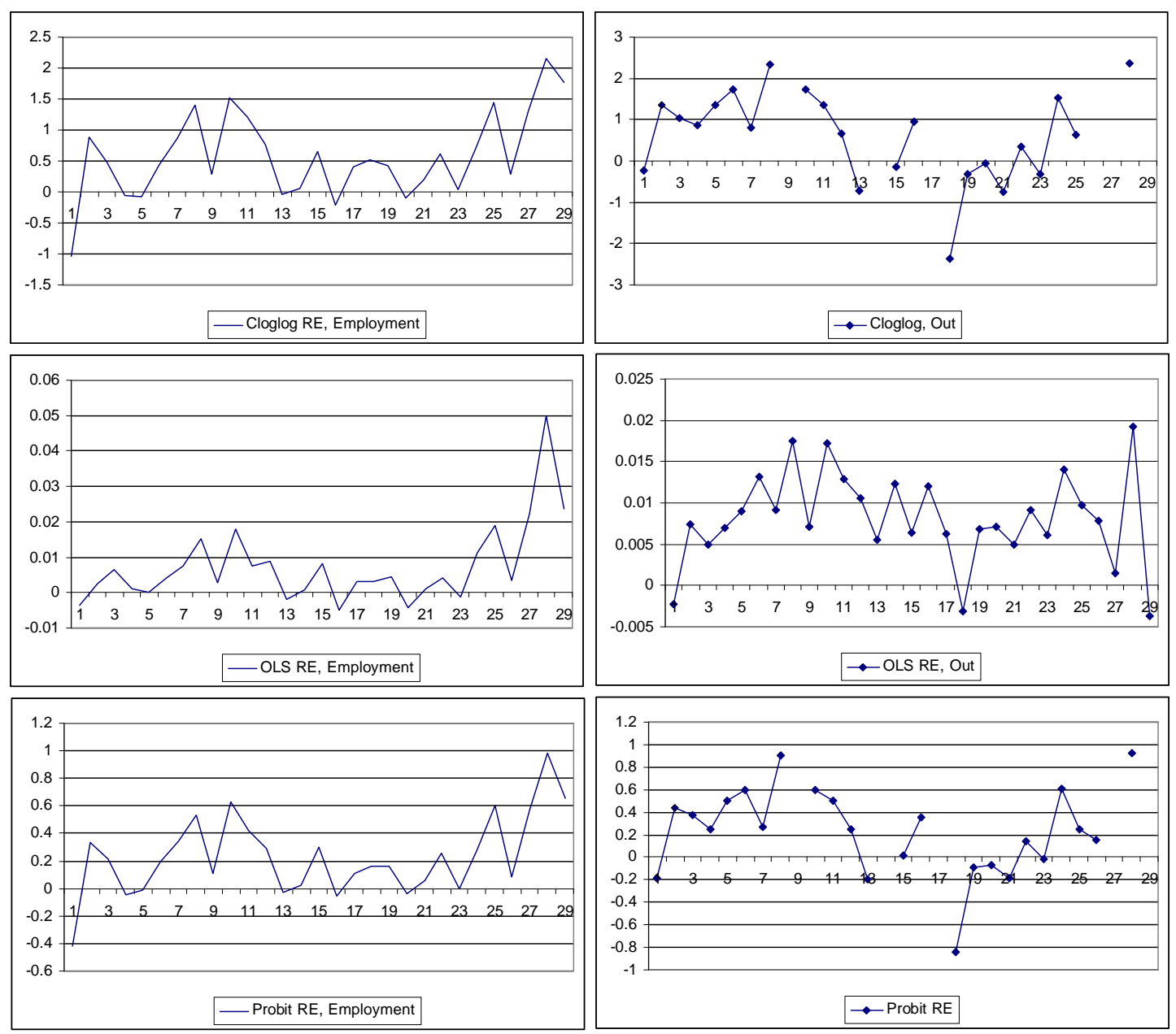

Figure 6: Time-varying treatment effect in models with different functional forms 
on the way the explanatory variables enter the equations. To mitigate this we have tried to do nearest neighbor matching initially and then to run our regressions on matched treatment and control groups. This yielded the same results. This is not surprising, since almost all our explanatory variables are dummies. ${ }^{19}$

Some of the assumptions/choices made regarding the construction of the event histories are susceptible to further scrutiny. First, for those with an immigration date before the start of public income transfer receipt (about $2 \%$ of the observations, equally distributed among treatments and controls), we had to make a choice. We tried three different strategies; the one applied in the paper was to fill in all blank initial periods with public income transfer receipt, if the blank period was followed by public income transfer receipt within three months after arrival. The amount of blank months filled in was approximately the same for the treatment and control groups. Another strategy would be to look at total payments made that year and evaluate if they corresponded to the number of months in public income transfer receipt, including the initial blanks. This strategy removed some of the blanks, but not all of them. A third strategy was to treat the individual as an immediate exit into non-participation, which in our opinion would be unfair to the experiment, and a fourth strategy would be to condition on income transfer receipt, that is, to start the duration clock at the time of recorded entry into the income transfer system. However, to do so for some, but not all, refugee immigrants (recall that those who never enter public income assistance are assigned a short duration initially so as to avoid selective sampling) would be inconsistent in our opinion. In any event, none of these changes would alter the main result, as the problem of initial blanks is distributed evenly among the treatment and control groups.

We have only looked at refugee immigrants, but actually the low level of transfer incomes apply to a more broadly defined group of individuals, namely, it applies to all individuals who have not spent seven of the last eight years in Denmark and who are eligible for public income transfers. However, it is not easy to identify the individuals eligible and not eligible for transfers from the data. We have tried to include individuals who were 'family-reunified' to refugees in 2002, since these are also under the 'Integration Law'. However, we have 'too many' individuals in this group compared to those analysed by the Ministry of Employment (2005), and a large fraction of them never receive starthelp, presumably because the spouse already has found employment and they are therefore not eligible. Moreover, it is not obvious who among them are entitled at all to receiving these payments, and these issues are difficult to clear up, and hence, we have not pursued this any further. Inclusion of all family-reunified individuals implies a dramatic increase in the transition rate into Out but has no impact on the transition rates into Employment. ${ }^{20}$

A re-definition of the dependent variable to measure the time until Employment, irrespective of whether the person is on temporary public income transfer or occupies the state 'Out', does not qualitatively alter the treatment effect on transitions into the state 'Employment'. One might have suspected that the loss of transfer income experienced when one spouse found a job would

\footnotetext{
${ }^{19}$ These results are not reported but are available on request.

${ }^{20}$ These results are not reported in the paper but are available on request from the authors.
} 
induce the other spouse to search more actively and hence find a job faster. We cannot detect such a response in the data. On the contrary, we find that if we include into this model a time-varying indicator for being 'Out', it is essentially zero, and in some cases negative, implying that these individuals find jobs at a lower rate. Moreover, interacting it with the treatment indicator, we see that the exit rate to Employment falls more when being 'Out' for those receiving the low starthelp than it does for those receiving cash assistance. ${ }^{21}$

\section{Conclusion}

In this study we have investigated the effect of the introduction of 'starthelp', that is, a lowering of the public income transfers administered to arriving refugee immigrants. We use reliable data sources that enable us to distinguish between exits from the public income transfer system to employment and non-participation. The results of the study show that - without taking calender time effects into account - there is a significant effect of starthelp on transition rate out of the public income transfer system and into employment. This effect seems to be stronger in the beginning of the spell than later.

Once calendar time effects are taken into account the pattern of the treatment effect on the transition reate into employment changes. This treatment effect is now smaller and it is largest after two years in Denmark, where refugees receiving starthelp have an increased transition rate of around $150 \%$.

The results also show that whether or not calender time effects are taken into account, there is a significantly positive effect of receiving starthelp on the transition rate out of the labour force during the first year in Denmark in the order of $80 \%$, which after one year falls to around $25 \%$ and becomes insignificant.

Turning to heterogenous effects, we find that the effect on the transition rate into employment is largest for De Facto and 'other' refugees, for those aged 30-50, for men, and for those with most education. Those with the smallest treatment effects are the least educated and women with (and without) children. For the transition out of the labour force, we find that the largest treatment effects are found for the best educated and for women with children, i.e. a fairly strong group and a group considered rather weak.

Using the MPH competing risk setup we have taken unobserved heterogeneity into account. The results suggest that correcting for unobserved heterogeneity is not that important.

This study shows that it is very important to account for the different exit possibilities, for composition of treatment and control groups, and especially for calendar time effects.

Analysing only transitions 'out of temporary public income transfers' would lead to estimated effects that confound exits in different directions at different times, and it would be difficult to learn anything useful from such an analysis. We provide a richer picture of the treatment effects

\footnotetext{
${ }^{21}$ These results are not reported in the paper but are available on request from the authors.
} 
than those reported by the Ministry of Employment (2005) and updated versions of their tabulations. Their estimates cannot formally be interpreted as treatment effects due to the neglect of composition effects, destination states, and calendar time effects. Whether our numbers can be interpreted as treatment effects depends on the degree of confidence in our clearly stated identifying assumptions. We have conducted robustness analyses along a number of dimensions, and the reported results are robust to all our attempted modifications in data configuration and the adopted methodology. Hence, we are faily confident that the results reported in this paper represent good estimates of the true treatment effects. It should be noted, though, that there are still some unresolved data issues that should be investigated further, but since they appear to affect treatment and control groups alike, we do not think these issues are responsible for the treatment effects found in this study.

Policy implications of the results depend on how a desirable outcome is defined; if the introduction of starthelp was motivated by the intention of getting refugee immigrants faster into employment, then it could be argued that it would be more appropriate to initially provide the refugee immigrants with higher transfer incomes to prevent their leaving the labour force, and then lower the income transfer level after a couple of years as employability is improved. Moreover, the heterogeneous treatment effects imply that women and the least educated are among the least responsive to the treatment with respect to finding employment, and that women with children are among the most likely to leave the labour force. Moreover, extended models show that while being outside the labour force and not receiving any income transfers, the transition rate into employment does not increase, rather there is a tendency to the opposite, despite the large economic incentive to finding employment. One potential consequence of these results is that the starthelp unintentionally sustains a family pattern, where only one spouse works in the labour market and the other performs domestic work. Hence, if the aim also is to achieve integration in a broader economic sense, defined both as high employment and participation rates and as positive contributions to the financing of the welfare state, the criterion for succes is employment - because it is a necessary condition for becoming a net contributor - and then the success of starthelp in its present form is difficult to spot.

\section{References}

[1] Abbring, J. H., G. J. van den Berg \& J. C. van Ours (2005), "The Effect of Unemployment Insurance Sanctions on the Transition Rate from Unemployment to Employment", The Economic Journal, Vol. 115, 602-630.

[2] Abbring, J.H. and G.J. van den Berg (2003a), "The non-parametric identification of treatment effects in duration models", Econometrica, Vol. 71, 1491-1517. 
[3] Abbring, J. H. and van den Berg, G. J. (2003b). The identifiability of the mixed proportional hazards competing risks model. Journal of the Royal Statistical Society: Series B (Statistical Methodology), Vol. 65, 701-710.

[4] Ai, C, EC Norton, (2003). Interaction terms in logit and probit models. Economics Letters, Vol. 80, 123-129.

[5] Bennmarker, H., K. Carling \& B. Holmlund (2005), "Do benefit hikes damage job finding? Evidence from Swedish unemployment insurance reforms", Working Paper 2005:22, IFAU, Uppsala (www.ifau.se).

[6] Bover, O., M. Arellano \& S. Bentolila (2002), "Unemployment duration, benefit duration and the business cycle", The Economic Journal, Vol. 112, 223-265.

[7] Carling, K., B. Holmlund \& A. Vejsiu (2001), "Do Benefit Cuts Boost Job Findings? Swedish Evidence from the 1990s", Economic Journal, Vol. 111, 766-790.

[8] Clausen, J. et al. (2006), Effekten af introduktionsprogrammets arbejdsmarkedsrettede indsats, Udkast

[9] Constant, A. \& M. L. Schultz-Nielsen (2004), Labor Force Participation and Unemployment: Incentives and Preferences. In Tranæs \& Zimmermann (Eds), Migrants, Work, and the Welfare State. University Press of Southern Denmark

[10] Hansen, F. K. \& H. Hansen (2004), Starthjælp og introduktionsydelse - Hvordan virker ydelserne? Center for Alternativ Samfundsanalyse

[11] Heckman, James \& Singer, Burton, (1984). "A Method for Minimizing the Impact of Distributional Assumptions in Econometric Models for Duration Data," Econometrica, Econometric Society, vol. 52(2), pages 271-320, March

[12] Lalive, R. \& J. Zweimüller (2004), "Benefit Entitlement and Unemployment Duration: The Role of Policy Endogeneity", Journal of Public Economics, Vol. 88, 2587-2616.

[13] Lancaster, T., (1990), The Econometric Analysis of Transition Data. Cambridge: Cambridge University Press.

[14] Ministry of Employment (2005), Afrapportering fra arbejdsgruppen om indsamling af oplysninger om virkning af introduktionsydelse på starthjcelpsniveau/starthjcelp, www.bm.dk/publikationer/2005/Starthjaelp/Rapport.pdf

[15] Mortensen, D. T. (1977), Unemployment Insurance and Job Search decisions. Industrial and Labor Relations Review, Vol. 30, 505-517. 
[16] Mortensen, D. T. (1986), Job Search and Labor Market Analysis. In O. Ashenfelter \& R. Layard (eds), Handbook of Labor Economics, Vol. 2, North-Holland, Amsterdam.

[17] Pedersen, P.J. \& Smith, N. (2002), "Unemployment Traps: Do Financial Disincentives Matter?", European Sociological Review, Vol. 18, No. 3, 271-288.

[18] Rosholm, M. \& O. Toomet (2005), "A search model of discouragement", IZA Discussion Paper 1633

[19] Røed, K. \& T. Zhang (2005), "Unemployment duration and economic incentives - A quasi random-assignment approach" , European Economic Review, Vol. 49, 1799-1825

[20] Strøm, S. (1998), Comment on B. Holmlund, "Unemployment Insurance in Theory and Practice", Scandinavian Journal of Economics, Vol 100, 146-152.

[21] Van Ours, J. C. \& M. Vodopivec (2004), "How Changes in Benefits Entitlement Affect JobFinding: Lessons from the Slovenian "Experiment" ", IZA Discussion Paper 1181, IZA, Bonn.

[22] Van Ours, J. C. \& M. Vodopivec (2006), "Shortening the Potential Duration of Unemployment Does Not Affect the Quality of Post-Unemployment Jobs: Evidence from a Natural Experiment", IZA Discussion Paper 2171, IZA Bonn.Van Praag, M.S \& A.

[23] Ferrer-i-Carbonell (2002), Life Satisfaction Differences between Workers and Non-workers The Value of Participation per se. TI Discussion Paper 2002-018/3, Tinbergen Institute.

[24] Xinghua, Y. (2006), "Competing Risk Analysis of Japan's Small Financial Institutions", IMES Discussion Paper No. 2006-E-7 


\section{Appendix A - more flexible models with calender time effects}

In this Appendix we estimate a more lfexible version of model 5 for both teh destinations Employment and Out. We use model 5 as our starting point and specify either treatment, calendar time or baseline fully flexible. The covariates are included in the estimation, but since the parameter estimates do not change very much they are not reported.

\subsection{Hazard into Employment}

Table 9 reports the results from the estimation of the employment hazard 
Table 9: Estimation results for more flexible models of the hazard into Job

\begin{tabular}{|c|c|c|c|c|c|c|}
\hline & \multicolumn{2}{|l|}{ Model 6} & \multicolumn{2}{|l|}{ Model 7} & \multicolumn{2}{|l|}{ Model 8} \\
\hline & Est. & Std.Err. & Est. & Std.Err & Est. & Std.Err \\
\hline Treatment effects & & & & & & \\
\hline $\begin{array}{l}\text { ATE Month 1-5 } \\
\text { ATE Month 6-12 } \\
\text { ATE Month 13-24 } \\
\text { ATE Month 25+ }\end{array}$ & $\begin{array}{r}-0.019 \\
\mathbf{0 . 8 4 6} \\
0.270 \\
\mathbf{1 . 0 2 8}\end{array}$ & $\begin{array}{l}0.371 \\
0.282 \\
0.240 \\
0.340\end{array}$ & $\begin{array}{r}-0.102 \\
\mathbf{0 . 8 6 7} \\
0.148 \\
\mathbf{1 . 1 1 5}\end{array}$ & $\begin{array}{l}0.434 \\
0.307 \\
0.177 \\
0.356\end{array}$ & & \\
\hline Fully flexible & & & & & Yes & \\
\hline Baseline & & & & & & \\
\hline Month 1 & -1.753 & 0.630 & & & -1.760 & 0.631 \\
\hline Month 2 & -3.359 & 0.754 & & & -4.756 & 1.152 \\
\hline Month 3-4 & -2.769 & 0.721 & & & -3.609 & 0.930 \\
\hline Month 5-8 & -3.362 & 0.775 & & & -4.116 & 0.972 \\
\hline Month 9 & -3.186 & 0.830 & & & -3.591 & 1.023 \\
\hline Month 10-11 & -3.230 & 0.844 & & & -4.435 & 1.078 \\
\hline Month 12-13 & -2.724 & 0.865 & & & -3.441 & 1.037 \\
\hline Month 14 & -2.101 & 0.928 & & & -2.790 & 1.079 \\
\hline Month 15-18 & -2.607 & 0.936 & & & -3.434 & 1.070 \\
\hline Month 19-21 & -2.423 & 0.975 & & & -3.315 & 1.083 \\
\hline Month 22 & -2.703 & 1.025 & & & -3.882 & 1.151 \\
\hline Month 23-24 & -2.203 & 1.007 & & & -3.170 & 1.094 \\
\hline Month 25 & -3.042 & 1.079 & & & -4.125 & 1.172 \\
\hline Month 26-29 & -2.245 & 1.076 & & & -3.144 & 1.111 \\
\hline Month 30-32 & -2.665 & 1.136 & & & -3.524 & 1.150 \\
\hline Month 35+ & -2.011 & 1.203 & & & -2.759 & 1.220 \\
\hline Fully flexible & & & Yes & & & \\
\hline Calender time & & & & & & \\
\hline Jan. 2002 (base) & & & & & & \\
\hline Feb. 2002 - May 2002 & & & -0.476 & 0.575 & -0.206 & 0.570 \\
\hline June 2002 & & & -1.380 & 0.888 & -1.026 & 0.882 \\
\hline July 2002 & & & -0.041 & 0.712 & 0.746 & 0.925 \\
\hline Aug. 2002 - Sept. 2002 & & & 0.563 & 0.676 & 1.257 & 0.868 \\
\hline Nov. 2002 - Feb. 2003 & & & -0.148 & 0.723 & 0.558 & 0.902 \\
\hline Mar. 2003 - Mar. 2004 & & & 0.576 & 0.813 & 1.255 & 0.954 \\
\hline Apr. 2004 - Aug. 2004 & & & 1.203 & 0.853 & 1.792 & 0.995 \\
\hline Sept. 2004 & & & 0.902 & 0.898 & 1.476 & 1.036 \\
\hline Oct. 2004 & & & 0.616 & 0.914 & 0.977 & 1.061 \\
\hline Nov. 2004 & & & -0.103 & 0.950 & 0.259 & 1.088 \\
\hline Jan. 2003 & & & 1.605 & 0.271 & 1.514 & 0.274 \\
\hline Jan. 2004 & & & 0.894 & 0.203 & 0.924 & 0.211 \\
\hline Dec. 2003 & & & -1.241 & 0.465 & -1.176 & 0.473 \\
\hline Fully flexible & Yes & & & & & \\
\hline Covariates & & & & & & \\
\hline Included & Yes & & Yes & & Yes & \\
\hline $\begin{array}{l}\text { Number of obs. } \\
\text { LoqLikelihood }\end{array}$ & & $\begin{array}{r}1728 \\
-2427.02\end{array}$ & & $\begin{array}{r}1728 \\
-2421.51\end{array}$ & & $\begin{array}{r}1728 \\
-2419.47\end{array}$ \\
\hline
\end{tabular}

Note: Numbers in bold are statistically significant at the $5 \%$ level.

As can be seen from this table the results do not change much. In the following, we present the estimates from the flexible part of model 6,7 and 8 . In figure 5 we present the estimates of the flexible calender time together with $5 \%$ confidence intervals from model 6 . As can be seen the calender time seems to be generally increasing in the period with spikes in January. In figure 6 the estimates from the flexible baseline from model 7 is presented. We see that it is almost flat but with a small positive slope. In Figure 7 the flexible treatment effect estimates from model 8 is shown. We see that the treatment effect is largest at the end of the period but that there is a small bump in the start and around month 11. Otherwise the curve seems to be quite flat. 


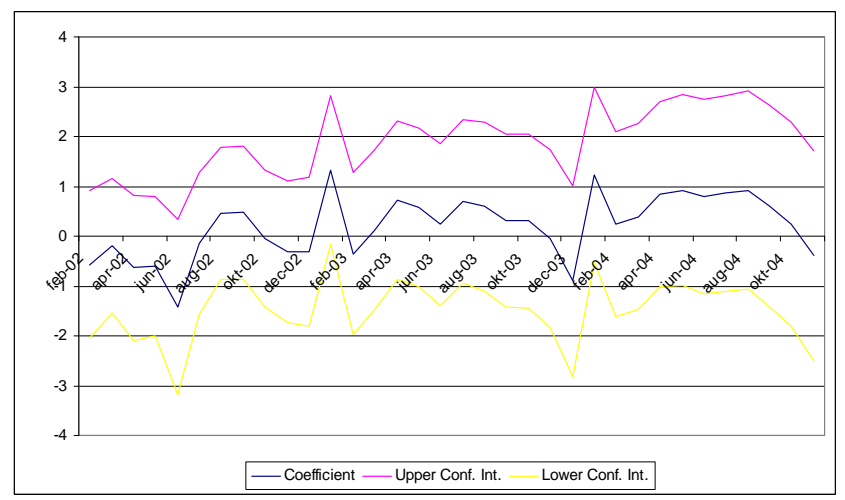

Figure 7: Calender time estimates from Model 6 for exit to Employment

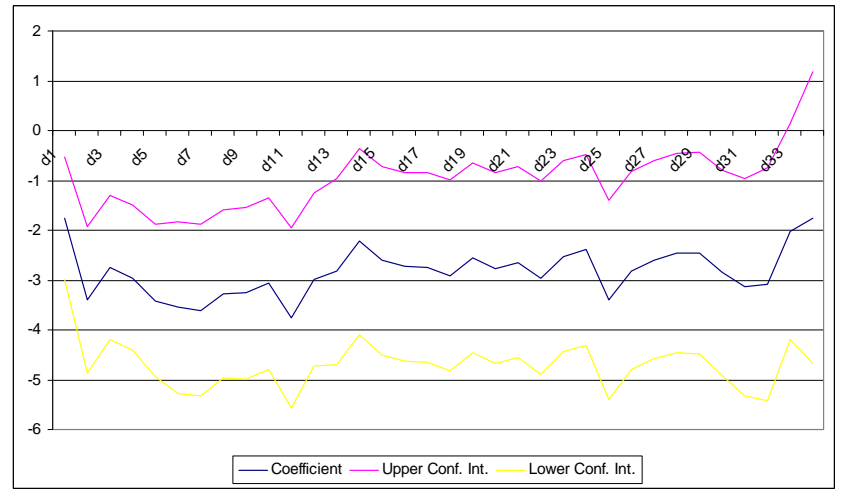

Figure 8: Baseline estimates from Model 7 for exit to Employment

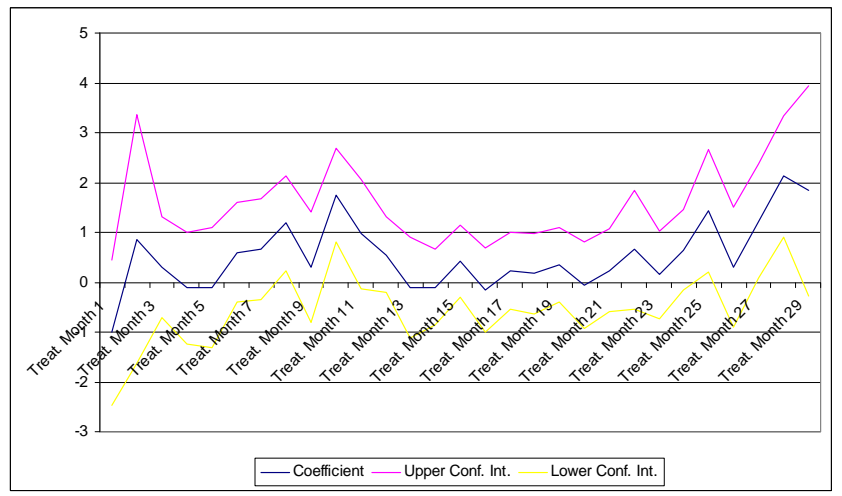

Figure 9: Treatment effect estimates from Model 8 for exit to Employment 


\subsection{Hazard Out of the Workforce}

Table 10 presents the results from the same kind of estimation but now on the hazard Out of the Workforce.

Table 10: Estimation results for more flexible models of the hazard into Out of the Workforce

\begin{tabular}{|c|c|c|c|c|c|c|}
\hline & Model 6 & & Model 7 & & |Model 8 & \\
\hline & Est. & Std. Err. & Est. & Std. Err & Est. & Std. Err \\
\hline \multicolumn{7}{|l|}{$\overline{\text { Treatment effects }}$} \\
\hline ATE Month 1-12 & 0.493 & 0.261 & 0.818 & 0.305 & & \\
\hline ATE Month $13+$ & 0.338 & 0.358 & 0.176 & 0.329 & & \\
\hline Fully flexible & & & & & Yes & \\
\hline \multicolumn{7}{|l|}{ Baseline } \\
\hline Month 1-11 & -4.496 & 0.897 & & & -4.558 & 0.899 \\
\hline Month 12-17 & -4.646 & 0.959 & & & -4.209 & 1.009 \\
\hline Month 18-22 & -4.053 & 1.001 & & & -3.028 & 1.042 \\
\hline Month 23-28 & -4.159 & 1.092 & & & -3.998 & 1.095 \\
\hline Month 29-33 & -3.371 & 1.203 & & & -2.974 & 1.158 \\
\hline Month 34+ & -2.934 & 1.386 & & & -2.223 & 1.301 \\
\hline Fully flexible & & & Yes & & & \\
\hline \multicolumn{7}{|l|}{ Calender time } \\
\hline \multicolumn{7}{|l|}{ Jan. 2002 (base) } \\
\hline Feb. 2002 - July 2002 & & & -0.385 & 0.778 & -0.793 & 0.748 \\
\hline Aug. 2002 - Apr. 2003 & & & -1.124 & 0.815 & -1.306 & 0.773 \\
\hline May 2003 - Feb. 2004 & & & -1.550 & 0.919 & -2.089 & 0.833 \\
\hline Mar. 2004 - May 2004 & & & -1.158 & 0.991 & -1.214 & 0.914 \\
\hline June 2004 - & & & -1.763 & 1.049 & -2.092 & 0.969 \\
\hline Fully flexible & Yes & & & & & \\
\hline \multicolumn{7}{|l|}{ Covariates } \\
\hline Included & Yes & & Yes & & Yes & \\
\hline Number of obs. & & 1728 & & 1728 & & 1728 \\
\hline LogLikelihood & & -1108.74 & & -1105.07 & & -1105.22 \\
\hline
\end{tabular}

Note: Numbers in bold are statistically significant at the $5 \%$ level.

Also here the results do not change much qualitatively. In Figures 8 to 10 below we present the flexible part of the models from Table 10. The holes in the graphs are from parameters not identified. In Figure 8 the calender time estimates together with confidence intervals from model 6 are presented. We see that the effect is fluctuating a bit and has a small negative slope. In figure 9 the baseline estimates from model 7 are shown. We see that the baseline is slowly increasing over time. In figure 10 the treatment effect estimates from model 8 are presented. We see that the treatment effect is largest (and only statistically significant) during the first year in Denmark and after a year it fluctuates around zero. 


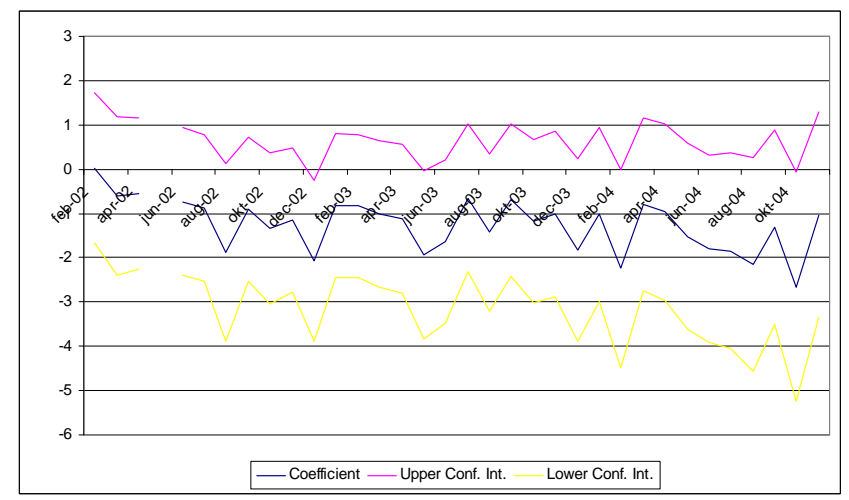

Figure 10: Calender time estimates from Model 6 for exit to Out of the Workforce

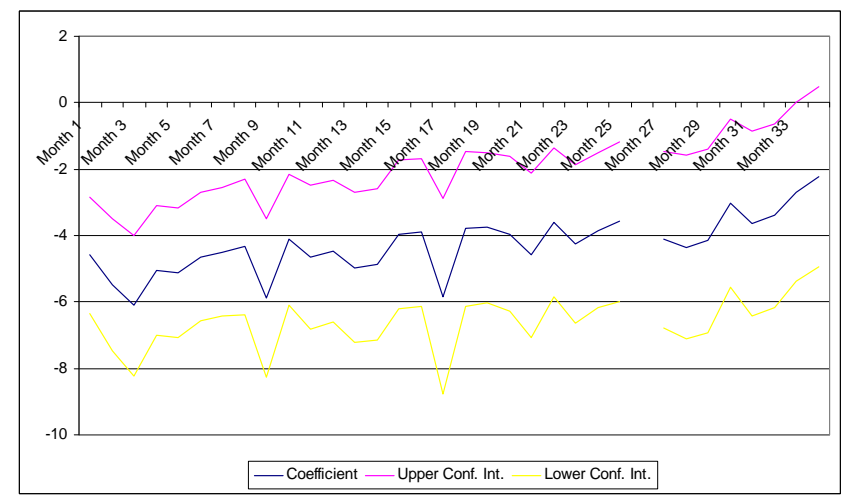

Figure 11: Baseline estimates from Model 7 for exit to Out of the Workforce

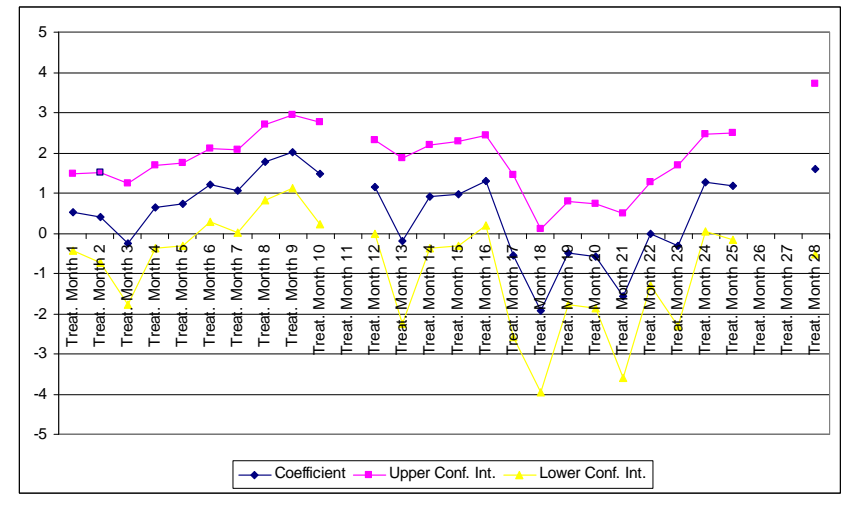

Figure 12: Treatment estimates from Model 8 for exit to Out of the Workforce 


\section{Appendix B - time-varying marginal interaction effects}

Table 11: Estimation results for interaction effects, Employment

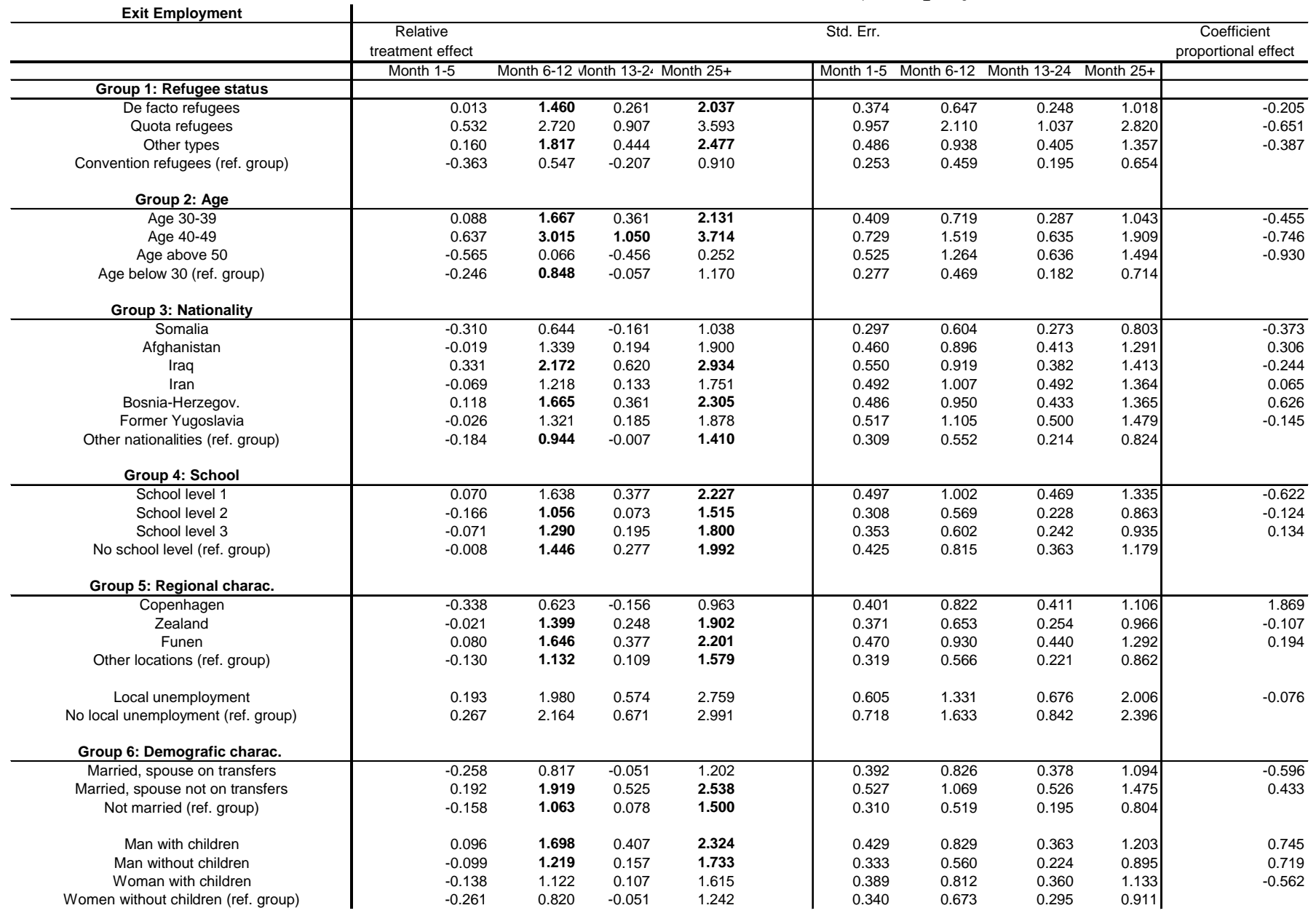


Table 12: Estimation results for interaction effects, Out

Exit Out

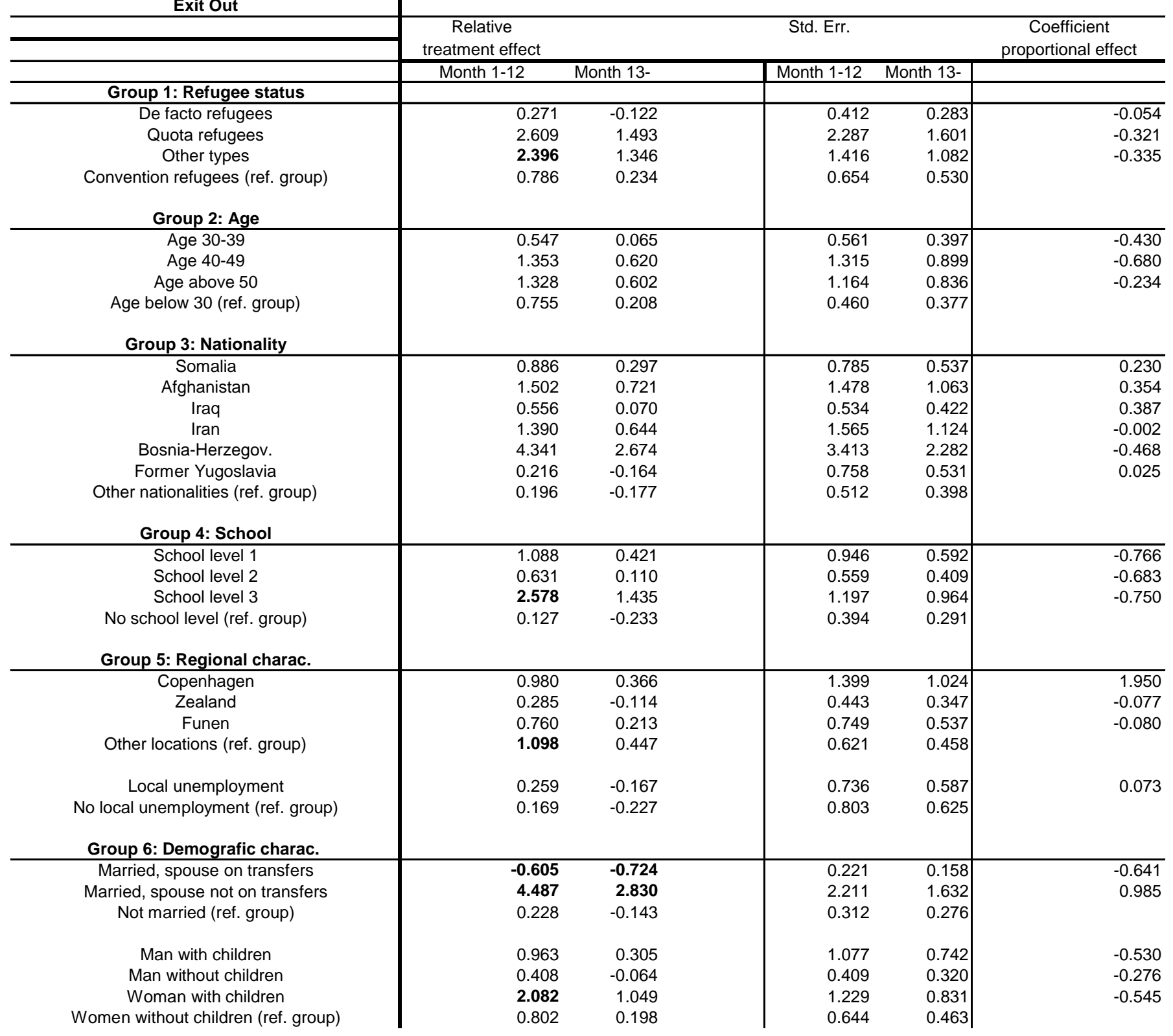




\section{Appendix C - Alternative functional forms}
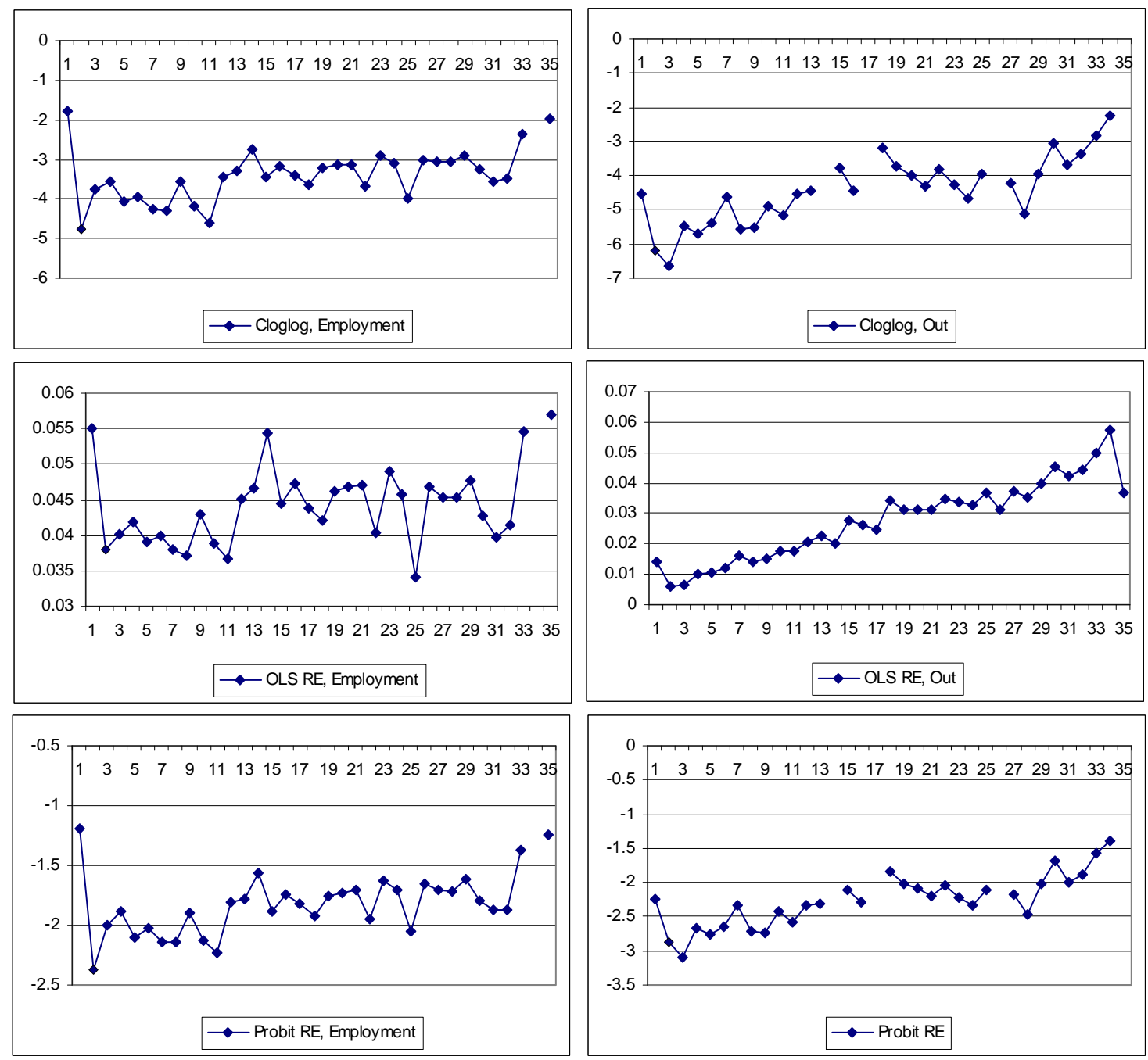

Figure 13: Baseline estimates for different functional forms 

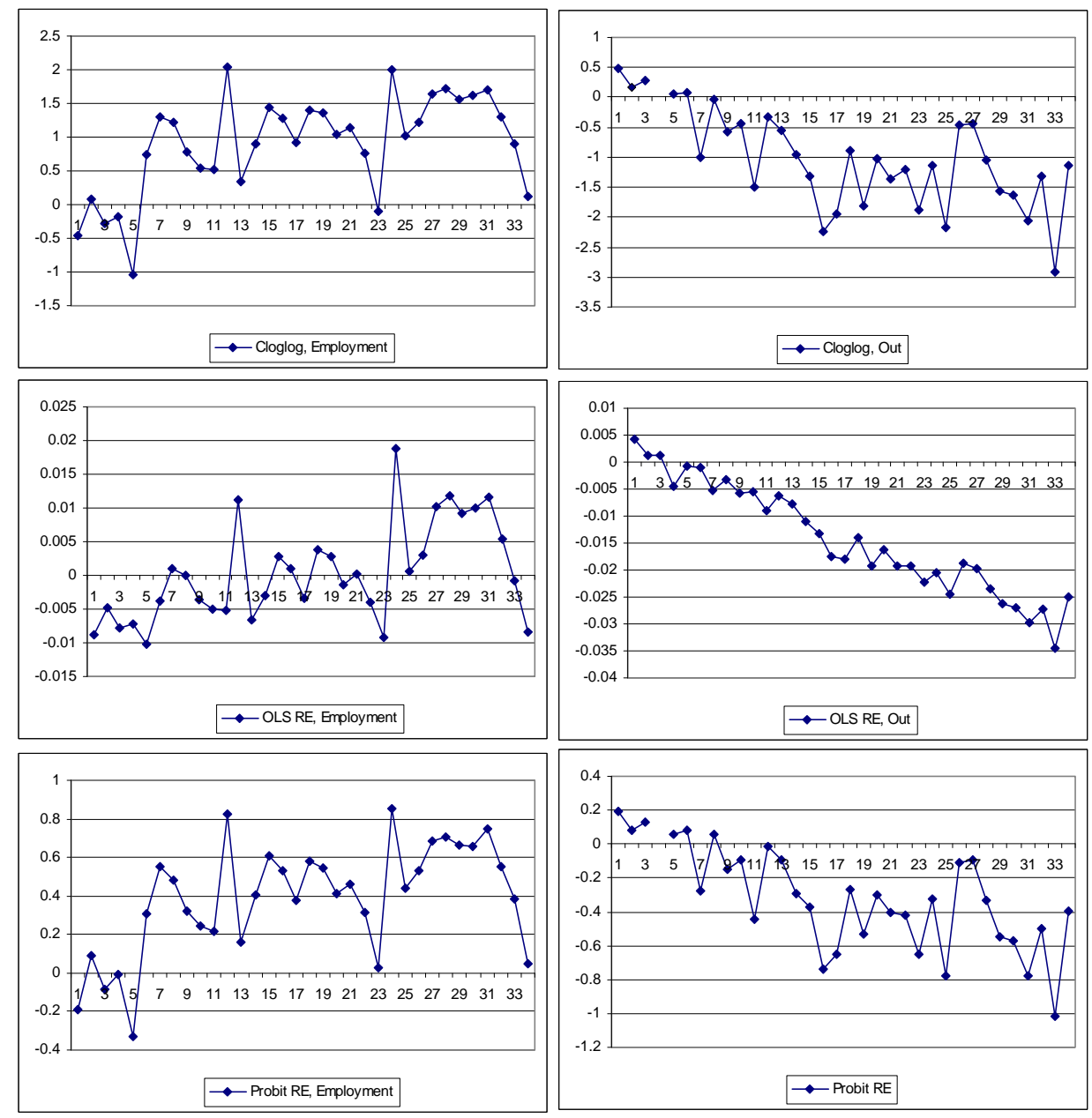

Figure 14: Calender time effects for different functional forms 